\title{
Informatiesysteem onderwijs-arbeidsmarkt voor de Euregio Maas-Rijn
}

Citation for published version (APA):

Teunis, U. (1995). Informatiesysteem onderwijs-arbeidsmarkt voor de Euregio Maas-Rijn.

Researchcentrum voor Onderwijs en Arbeidsmarkt, Faculteit der Economische Wetenschappen. ROA Reports No. 2 https://doi.org/10.26481/umarep.1995002

Document status and date:

Published: 01/01/1995

DOI:

10.26481/umarep.1995002

Document Version:

Publisher's PDF, also known as Version of record

\section{Please check the document version of this publication:}

- A submitted manuscript is the version of the article upon submission and before peer-review. There can be important differences between the submitted version and the official published version of record.

People interested in the research are advised to contact the author for the final version of the publication, or visit the DOI to the publisher's website.

- The final author version and the galley proof are versions of the publication after peer review.

- The final published version features the final layout of the paper including the volume, issue and page numbers.

Link to publication

\footnotetext{
General rights rights.

- You may freely distribute the URL identifying the publication in the public portal. please follow below link for the End User Agreement:

www.umlib.nl/taverne-license

Take down policy

If you believe that this document breaches copyright please contact us at:

repository@maastrichtuniversity.nl

providing details and we will investigate your claim.
}

Copyright and moral rights for the publications made accessible in the public portal are retained by the authors and/or other copyright owners and it is a condition of accessing publications that users recognise and abide by the legal requirements associated with these

- Users may download and print one copy of any publication from the public portal for the purpose of private study or research.

- You may not further distribute the material or use it for any profit-making activity or commercial gain

If the publication is distributed under the terms of Article $25 \mathrm{fa}$ of the Dutch Copyright Act, indicated by the "Taverne" license above, 


\section{Informatiesysteem onderwijs-arbeidsmarkt voor de Euregio Maas-Rijn}

ROA-R-1995/2

U. Teunis

\section{Researchcentrum voor Onderwijs en Arbeidsmarkt}

Faculteit der Economische Wetenschappen

Rijksuniversiteit Limburg

Maastricht, maart 1995 


\section{CIP-GEGEVENS KONINKLIJKE BIBLIOTHEEK, DEN HAAG}

Teunis, $U$.

Informatiesysteem onderwijs-arbeidsmarkt voor de Euregio Maas-Rijn / U. Teunis. Maastricht : Researchcentrum voor Onderwijs en Arbeidsmarkt, Faculteit der Economische Wetenschappen, Rijksuniversiteit Limburg. - (Rapport / Researchcentrum voor Onderwijs en Arbeidsmarkt, ISSN 0922-8098 ; ROA-R-1995/2)

Met lit. opg.

ISBN 90-5321-155-1

Trefw.: informatiesystemen / onderwijs en arbeidsmarkt. 


\section{Inhoudsopgave}

Pagina

Voorwoord

1 Inleiding

1

1.1 Aanleiding

1

1.2 Uitwerking probleemstelling

1.3 De Euregio Maas-Rijn: situatieschets

2 De behoefte aan een informatiesysteem $\quad 7$

2.1 Algemeen 7

2.2 Het beeld in Zuid-Limburg 8

2.3 Het beeld in (Belgisch) Limburg 11

2.4 Het beeld in Duitsland 16

2.5 Het Euregio-bestuur 19

2.6 Resumerend: de potentiële vraag 19

3 De beschikbaarheid van gegevens 25

3.1 Algemeen 25

3.2 De Euregionale arbeidsmarkt $\quad 26$

$\begin{array}{ll}3.3 \text { De aansluiting onderwijs-arbeidsmarkt } & 29\end{array}$

3.4 Kwalitatieve signalementen 30

3.5 Informatie over onderwijs en opleidingen 31

3.6 Informatie op Euregio-niveau 31

3.7 Resumerend: de mogelijkheden 32

4 De ontwikkeling van een informatiesysteem 35

4.1 Conclusies $\quad 35$

4.2 Vorm en functie van een informatiesysteem 35

4.3 Gefaseerde ontwikkeling 37

4.4 Globale planning, organisatie 39

$\begin{array}{ll}\text { Literatuur } & 41\end{array}$ 



\section{Voorwoord}

In maart 1994 heeft het ROA een onderzoeksvoorstel voorgelegd aan het Ministerie van (destijds) Onderwijs en Wetenschappen, directie Beroepsonderwijs en Volwasseneneducatie (BVE), voor een pilotstudy betreffende de informatievoorziening ten behoeve van grensoverstijgende mobiliteit, uit te voeren in en ten behoeve van de Euregio Maas-Rijn. In mei 1994 heeft het ministerie subsidie toegekend voor uitvoering van deze pilotstudy.

In de inleiding wordt de gehanteerde werkwijze verantwoord. In hoofdstuk 1 worden aanleiding en probleemstelling nader geanalyseerd tegen de achtergrond van de ontwikkelingen in de Euregio. Verder worden in hoofdstuk 2 en 3 achtereenvolgens de behoeften aan een Euregionaal informatiesysteem geanalyseerd en de mogelijkheden op het vlak van beschikbaarheid van gegevens verkend. Tot slot worden een aantal conclusies aangaande behoeften en mogelijkheden gepresenteerd en wordt een voorstel gedaan voor de opzet van dit informatiesysteem.

Het rapport wordt uitgebracht aan de opdrachtgever. Het zal tevens voor advies worden aangeboden aan de Stichting Euregio Maas-Rijn, in het bijzonder de werkgroep beroepsopleiding en volwasseneneducatie en aan de stuurgroep EURES binnen de Euregio. Doel van deze advisering is respons te krijgen vanuit de meest betrokken instanties binnen de Euregio. Het advies van de werkgroep respectievelijk de stuurgroep zal tevens de grondslag vormen voor een verzoek tot (co)financiering van de eigenlijke ontwikkeling van het informatiesysteem.

Verantwoording werkwijze

De pilotstudy is uitgevoerd door middel van literatuurstudie en interviews.

\section{Literatuurstudie}

Er is vooral gezocht naar literatuur betreffende:

* de situatie in de Euregio, waarbij de aandacht vooral uitging naar de terzake gebruikte informatie(bronnen);

* mogelijke behoeften aan bepaalde typen informatie;

* beschikbaarheid van gegevensbronnen;

* vergelijkbare informatie-projecten en -producten.

Er is weinig aandacht besteed aan theoretische fundering, bijvoorbeeld betreffende de functie van informatiesystemen binnen openbaar bestuur en binnen regionale economische ontwikkeling. Op dit punt wordt verwezen naar andere ROA-publicaties 
(onder meer Van Dam, De Grip en Heijke, 1992) en naar het project 'International Labour Market Indicators'1.

Interviews

De interviews waren open, zij het enigszins voorgestructureerd door middel van een aantal gesprekspunten in de bevestigingsbrief. De telkens terugkerende hoofdvragen waren:

* het soort gegevens dat de betreffende instelling gebruikt en genereert in verband met de uitvoering van haar taken;

* de mogelijke behoefte aan informatievoorziening onderwijs-arbeidsmarkt op het niveau van de Euregio;

* de mogelijkheid en bereidheid bij de instelling gegevens voor een informatiesysteem terzake beschikbaar te stellen;

* de mogelijke bereidheid werkelijk van een informatiesysteem gebruik te maken.

In enige interviews kwam daarnaast de mogelijkheid van en bereidheid tot samenwerking bij het realiseren van een informatiesysteem aan de orde.

Interviews hebben plaatsgevonden met (in volgorde van tijd):

* dhr. J. Hagenaars, RDC Limburg;

* dhr. G. Wolfs, dhr. van Lieshout, Provincie Limburg;

* dhr. P.C.M. Hanraets, ETIL;

* dhr. L.L.M. Frederix, RBA, coördinator EURES (samen met dhr. De Grip);

* dhr. H. Dejonckheere, steunpunt WAV, dhr. P. Van der Hallen, steunpunt WAV/HIVA (samen met dhr. De Grip);

* dhr. F. Aarts, arbeidsbureau Heerlen;

* dhr. H.G. Kerzenbaum, dhr. K. Kaever, dhr. Werner, Arbeitsamt Aachen;

* dhr. U. Michelsen, dhr. Löffler, RWTH, Institut für Erziehungswissenschaft;

* dhr. H.W. Breuer, RWTH, Lehrstuhl angewannte Geografie;

* mw. A. Bakos, strategisch plan Limburg te Hasselt;

* mw. I. Bold, mw. R. Buxbaum, Regio Aachen;

* dhr. W. Siemons, Industrie- und Handelskammer zu Aachen;

* dhr. P. Willems, Gewestelijke Ontwikkelings Maatschappij (GOM) te Hasselt;

* dhr. M. Smets, dhr. J.P. Boons, VDAB Hasselt;

* dhr. L. Richter, bureau Stichting Euregio Maas-Rijn;

* mw. F. Quanten, Permanente Werkgroep Limburg te Hasselt.

1. Dit ontwikkelingsproject wordt thans, eveneens in opdracht van het ministerie van OCW, door het ROA uitgevoerd. Er zijn raakvlakken tussen beide projecten op het vlak van de methodiek en de inventarisatie van gegevensbronnen. Waar van toepassing wordt in dit rapport naar de komende rapportage van dit project verwezen. 
De geïnterviewden worden in dit rapport verder niet op naam aangehaald. Waar van toepassing wordt verwezen met "mededeling in interview".

Zoals uit bovenstaand overzicht blijkt konden niet alle potentieel relevante instellingen voor een interview worden benaderd. Ook in de literatuurstudie is niet over alle relevante instellingen informatie aangetroffen. De beschikbare tijd heeft tot zekere beperkingen aanleiding gegeven; bovendien bleek vooral in de opstart-fase veel tijd nodig om het 'institutionele netwerk' te verkennen, waarna het benaderen van alle relevante actoren niet meer haalbaar bleek. Beperkingen zijn er vooral ten aanzien van:

* de economische Kamers in de drie landsdelen; er heeft alleen een gesprek plaatsgevonden met de Industrie- und Handelskammer zu Aachen.

* werkgevers- en werknemersorganisaties.

* gemeentelijke overheden, b.v. in verband met het zogenaamde MHAL-project (samenwerkingsverband Maastricht-Hasselt/Genk-Heerlen-Aachen-Liège).

* het provinciebestuur van (Belgisch) Limburg.

* onderwijsinstellingen of vertegenwoordigende organisaties van het onderwijs.

* bedrijven of vertegenwoordigende organisaties op branche- of sectorniveau.

* overeenkomstige instellingen in de provincie Liège en, daarbinnen, de Duitstalige gemeenschap; het gebruik van het Frans zou de verkenning in deze provincie extra tijdrovend hebben gemaakt. 



\section{Inleiding}

\subsection{Aanleiding}

Aanleiding tot het onderzoeksvoorstel vormde de constatering dat grensoverschrijdende mobiliteit in toenemende mate in de belangstelling staat, vooral in verband met de voortschrijdende integratie van de (arbeids)markt binnen de Europese Unie. De verschillende Europese verdragen en initiatieven op het vlak van het vrije verkeer van arbeid winnen daardoor aan actualiteit. Ondanks deze verdragen en initiatieven en de algemene tendens tot internationalisering van de economie neemt de grensoverschrijdende mobiliteit, als percentage van het totaal aantal arbeidskrachten, nog steeds een bescheiden plaats in. Dit geldt zowel voor mobiliteit in de vorm van (semi)permanent verblijf in een andere lidstaat als voor de zogenaamde grenspendel. Bovendien is de binnen-Europese mobiliteit klein in vergelijking met de migratie van arbeid van buiten de Europese unie. Blijkbaar 'loont' grensoverschrijdende mobiliteit binnen de EU nog te weinig, en/of zijn er nog steeds aanzienlijke barrières die een toename van de migratiestroom in de weg staan. Die barrières zijn inderdaad aanwijsbaar, in de sfeer van het functioneren van de arbeidsmarkt, de institutionele structuren ten behoeve van de arbeidsmarkt, onderwijs en scholing en belastingen en sociale zekerheid (zie ook Van Dam, De Grip en Heijke, 1992). Deze pilotstudy heeft als invalshoek het slechte van deze barrières, voorzover die gelegen zijn op het vlak van informatie over het onderwijs en de arbeidsmarkt en de aansluiting daartussen.

Grensregio's hebben door hun ligging in het bijzonder met deze barrières te maken. Logischerwijs is de grensoverschrijdende mobiliteit in deze regio's omvangrijker dan elders, vooral in de vorm van grenspendel. Door hun positie in de periferie is de economische ontwikkeling van deze regio's veelal ongunstig geweest. In theorie zouden zij het meest profijt kunnen trekken van een toenemende grensoverschrijdende mobiliteit, niet alleen van arbeid maar ook van kapitaal (investeringen, bedrijfsvestigingen) en bedrijvigheid (handels- en vervoersstromen, maar ook b.v. scholingsactiviteiten). Daarom is ervoor gekozen deze pilot-study vooral op deze grensregio's te richten.

Een aantal grensregio's is verenigd in zogenaamde Euregio's. Dit zijn samenwerkingsverbanden (met diverse rechtspersoonlijkheid) die de economische, sociale en culturele ontwikkeling binnen de aangrenzende regio's trachten te bevorderen. De opzet en doelstellingen hangen samen met die van het INTERREG-programma van de EU: "aan de binnen- en buitengrenzen gelegen gebieden van de Europese Unie behulpzaam te zijn bij het overwinnen van bijzondere ontwikkelingsproblemen die voortkomen uit hun relatieve afzondering binnen de nationale economieën ....; stimulansen te geven om netwerken voor samenwerking over binnengrenzen heen op te richten en te ontwikkelen" (Publicatieblad van de Europese Gemeenschappen, 
1994); "het bevorderen van grensoverschrijdende samenwerking en het versterken van de (economische) structuur binnen de grensregio's van de Europese Unie" (Mededeling provincie Limburg oktober 1994).

Deze pilot-study is uitgevoerd binnen de Euregio Maas-Rijn. Grond voor de keuze, de pilotstudy hier uit te voeren, vormen de unieke kenmerken en mogelijkheden van de Euregio Maas-Rijn. Als enige van alle Euregio's verenigt zij grensregio's uit drie landen (Duitsland, Nederland en België) en drie taalgebieden (Duits, Nederlands en Frans). Zij verenigt bovendien gebieden met enerzijds grote economische en sociale problemen, anderzijds een groot ontwikkelingspotentieel. Tot slot zijn in deze Euregio reeds diverse initiatieven genomen tot samenwerking op het terrein van onderwijs en arbeidsmarkt, zodat hier zowel de behoeften aan als de mogelijke effecten van verbeterde informatievoorziening goed kunnen worden onderzocht. Het ROA heeft eerder onderzoek gedaan ten behoeve van deze Euregio (zie Van Dam en De Grip, 1991; Meijboom 1992; Van Dam, De Grip en Heijke 1992). Deze onderzoeken hebben conclusies en aanbevelingen opgeleverd, waarop in deze pilot-study is voortgebouwd (zie verder paragraaf 1.3).

\subsection{Uitwerking probleemstelling}

Zoals boven vermeld bouwt deze pilotstudy voort op eerdere ROA-studies in en voor de Euregio Maas-Rijn. Van Dam et al. concluderen in 1992 onder meer dat de ontwikkeling van de Euregionale arbeidsmarkt wordt belemmerd door "onvoldoende inzicht bij werkgevers en potentiële pendelaars in de vraag-aanbodverhoudingen aan de andere zijde van de grens. Het ontbreekt niet alleen aan uniforme en gedetailleerde arbeidsmarktgegevens, maar ookaan een laagdrempelige geïntegreerde voorlichting".

Zij doen hierover een aantal aanbevelingen:

* op continue basis inzicht verschaffen in de vraag-aanbodverhoudingen naar bedrijfstak, beroep en opleiding.

* grensoverschrijdende uitwisseling van informatie overwerkzoekenden envacatures volgens een uniform classificatiesysteem.

* ondersteuning van het geplande 'euroloket' van de organisaties van de arbeidsvoorziening.

* uitwisseling van bemiddelingsfunctionarissen door middel van stages en detacheringen.

Ten aanzien van het onderwijs concluderen Van Dam et al. onder meer "dat er in de Euregio geen enkele afstemming plaatsvindt van de aanwezige opleidingscapaciteit op de behoeften aan de andere zijde van de grens en dat men doorgaans nauwelijks toegang heeft tot de onderwijsstelsels in de buurlanden. Een specifiek knelpunt is het ontbreken van een Euregionaal overzicht van de vraag naar en het aanbod van opleidings- en scholingsmogelijkheden en de daarbij gestelde vooropleidingseisen". Ook 
voor een betere afstemming op dit terrein wordt een betere informatievoorziening van belang geacht. Geadviseerd wordt de ontwikkeling van een 'Euregio statistiek' met gegevens over de bevolking, de economische structuur en de arbeidsmarkt. Deze zou een nuttige rol kunnen vervullen bij de gewenste netwerkvorming binnen de Euregio, als informatiebron kunnen fungeren bij het signaleren van knelpunten en informatie kunnen aandragen voor het evalueren van de effectiviteit van beleidsinitiatieven.

Zoals uit het verdere rapport zal blijken is sinds 1992 op enige punten vooruitgang geboekt; de meeste conclusies en de daaraan verbonden aanbevelingen blijven echter rechtovereind. In het onderzoeksvoorstel voor de pilotstudy (zie Inleiding) wordt daarom aangesloten bij de voorstellen van Van Dam et al. voor het verbeteren van het functioneren van de interregionale arbeidsmarkt. Verder wordt aangesloten bij actuele ontwikkelingen als de ontwikkeling van een systeem voor erkenning en waardering van diploma's. Samenvattend omvat het onderzoeksvoorstel dus een nadere verkenning naar de behoeften aan en mogelijkheden tot verbetering van de informatievoorziening betreffende de 'vraagkant' (vraag naar arbeid, kwalificatievereisten e.d.) en de 'aanbodkant' (aanbod van kwalificaties, mogelijkheden van waardering en erkenning, mogelijkheden voor onderwijs en scholing e.d.). De pilotstudy zou daartoe een inventarisatie moeten omvatten "van institutionele en informatorische voorzieningen ten behoeve van grensoverschrijdende aansluiting onderwijsarbeid ... en de knelpunten die op dat terrein worden ervaren". De pilot-study dient te resulteren in een onderzoeks- c.q. ontwikkelingsvoorstel dat mede de grondslag kan vormen voor een aanvraag tot subsidiëring uit het INTERREG-II-programma. Tot slot: de pilotstudy en het aansluitend ontwikkelingsproject worden uitgevoerd binnen en ten behoeve van de Euregio Maas-Rijn, maar het te ontwikkelen informatiesysteem dient overdraagbaar te zijn naar andere Euregio's.

Tijdens de uitvoering van de pilotstudy is (met kennisgeving aan de opdrachtgever) besloten tot een beperking van de vraagstelling. Voornaamste reden hiervoor was dat in de eerste ronde interviews en in de literatuur vooral een mogelijke behoefte aan informatie over de arbeidsmarkt en de aansluiting onderwijs-arbeid naar voren kwam, en in veel mindere mate aan informatie over institutionele voorzieningen ten behoeve van grensoverschrijdende mobiliteit en over diplomawaardering en -erkenning. De betrokken instellingen zijn deels zelf reeds intensief betrokken bij deze institutionele voorzieningen (met name heeft de ontwikkeling van de zogenaamde euroloketten verder vorm gekregen); op dit punt zijn ook diverse samenwerkingsverbanden over de grenzen heen aanwijsbaar. Op het vlak van de diplomawaardering en -erkenning zijn, mede als gevolg van Europese regelgeving, in de verschillende landen recentelijk institutionele voorzieningen getroffen (zie o.a. Bosker 1994).

Daartegenover bleek een grote behoefte aan meer kwalitatieve informatie aangaande ontwikkelingen aan de vraagkant van de arbeidsmarkt (zie verder hoofdstuk 2). 
Daarom zijn de mogelijkheden voor zowel een kwantitatief als een kwalitatief informatiesysteem onderwijs-arbeidsmarkt onderzocht. Een andere behoefte die sterk naar voren kwam was die aan informatie over de onderwijssystemen van de betrokken landen op een meer gedetailleerd en inhoudelijk niveau, met het oog op b.v. doorverwijzing naar onderwijsinstellingen over de grens, gezamenlijke cursusplanning, streven naar vormen van 'bi-diplomering' of 'tri-diplomering' (diploma's met civiel effect in twee respectievelijk drie van de betrokken landen) e.d. Daarom is dit element in de advisering in dit rapport meegenomen.

\subsection{De Euregio Maas-Rijn: situatieschets}

De Euregio Maas-Rijn omvat de gebieden in Duitsland Heinsberg, Aachen, Düren en Euskirchen (verenigd in de 'Regio Aachen), in Nederland de regio Zuid Limburg en in België de provincies Limburg en Liège; binnen de Franstalige provincie Liège vormt de 'Deutschsprachige Gemeinschaft' als semi-autonome regio een afzonderlijke partner binnen de Euregio (voor verdere informatie over de bestuurlijke structuur van de Euregio, zie paragraaf 2.5). Het gebied ligt tussen grote, maar deels kwijnende, industriegebieden: Ruhr, Wallonië, Rijnmond. De grotendeels verdwenen mijnbouw vormt een gemeenschappelijke geschiedenis. Mede als gevolg van de mijnsluitingen en het achteruitgaan van de in de regio dominante deels verouderde industrietakken (onder meer staal en keramica) kennen (of kenden) al deze gebieden een relatief hoge werkloosheid en een gemiddeld lage scholingsgraad. In alle drie landsdelen van de Euregio zijn echter conversieprogramma's in uitvoering, gericht op de opvang van de gevolgen van zowel de mijnsluitingen als de veranderingen in de economische structuur; gemeenschappelijke noemer van deze programma's is de nadruk op bevordering van groei van de dienstensector en van het midden- en kleinbedrijf. In ieder geval in Nederland en België zijn omvangrijke infrastructurele maatregelen getroffen, gericht op de verplaatsing van werkgelegenheid en versterking van de kennisinfrastructuur (onder meer vestiging van de belastingdienst, een deel van het CBS en de Open Universiteit in Heerlen; vestiging van een universiteit resp. universitaire vestiging in Maastricht en Diepenbeek).

Naar is aan te nemen mede als gevolg van deze conversie-programma's is de economische ontwikkeling in deze Euregio sinds de economische crisis begin jaren ' 80 relatief gunstig geweest (zie onder meer L-SEV '93). Aangezien echter het aandeel van de industrie in de totale werkgelegenheid relatief groot is, is de werkgelegenheidsontwikkeling in deze regio's gevoeliger voor conjunctuurschommelingen dan landelijk het geval is. De laagconjunctuur van de jaren '91-'93 heeft dan ook tot een relatief grotere terugloop van werkgelegenheid geleid dan elders.

In (Nederlands) Limburg is de ontwikkeling in de jaren '80 in vergelijking met Nederland als geheel relatief gunstig geweest, zowel in termen van arbeidsvolume als van 
arbeidsplaatsen. Vooral in het midden- en kleinbedrijf is de groei relatief snel geweest. Waarschijnlijk gaat het bij deze groei echter voor een deel om 'overdracht' van werkgelegenheid van grote naar kleinere bedrijven, als gevolg van verzelfstandiging en uitbesteding. Omdat de beroepsbevolking in de provincie sneller terugloopt dan in Nederland als geheel, is de werkloosheid gedaald tot onder het landelijk gemiddelde. Binnen Limburg is echter de positie van Zuid-Limburg op de meeste indicatoren het minst gunstig. Als gevolg van genoemde conjunctuurgevoeligheid heeft de crisis begin jaren ' 90 geleid tot verminderde werkgelegenheid in de grote bedrijven en (in geringere mate) in het midden- en kleinbedrijf $(-0,25 \% ;+1 \%$ in de bedrijven tot 50 werknemers). Groei zit voornamelijk nog in de commerciële dienstverlening; de groei in de kwartaire sector is geheel tot staan gekomen. In 1994 herstelt zich de economische groei met 1,5 à $2 \%$; voor 1995 wordt een groei van meer dan $3 \%$ verwacht. De totale werkloosheid is in 1994 nog wel toegenomen, maar in 1995 wordt een daling verwacht, in verband met de relatief langzaam groeiende beroepsbevolking zelfs meer dan landelijk (L-SEV 1994).

In (Belgisch) Limburg is ook sprake van een naar verhouding gunstige ontwikkeling. De werkgelegenheid is hier tot 1991 sterk gestegen, ondanks de vrijwel volledige sluiting van de steenkoolmijnen in deze periode. Deze ontwikkeling wordt mede in verband gebracht met de stimulerende maatregelen in het kader van het reconversiebeleid (Van Hilst, 1993). Ook hier zit de groei voornamelijk in het midden- en kleinbedrijf; deeltijd- en uitzendwerk is naar verhouding sterk toegenomen. De werkloosheid is in de jaren ' 80 relatief sterk gedaald, maar desondanks nog steeds de één na hoogste onder de Belgische provincies (Van Hilst 1993; Gewestelijke Ontwikkelingsmaatschappij Limburg, 1995). Het hoogste werkloosheidspercentage heeft de provincie Luik. Ook in vergelijking met de andere landsdelen binnen de Euregio Maas-Rijn lijkt de economische situatie in Liège het minst gunstig (L-SEV'94).

Ook in het Duitse deel van de Euregio (hier verder aangeduid als Regio Aachen) is de economische situatie relatief ongunstig in termen van werkgelegenheid en productiviteit. Ook hier is echter de ontwikkeling in de laatste jaren positief (Arbeitsamt 1994). Ook hier groeit relatief het midden- en kleinbedrijf en de commerciële dienstverlening; de aanwezigheid van de technische hogeschool stimuleert de groei van 'High Tech' bedrijven. Probleem is daarbij wel dat deze nieuwe werkgelegenheid maar zeer ten dele de uitstoot uit de oude industrie kan opvangen (mededelingen in interview).

Voor de hele Euregio geldt dat deze binnen het Europa zonder binnengrenzen eerder centraal dan perifeer is gelegen en dat op diverse punten een groot ontwikkelingspotentieel aanwijsbaar is (zie Van Dam, De Grip en Heijke, 1993). 
Tabel 1.1

Enige kengetallen Euregio Maas-Rijn

\begin{tabular}{lllll}
\hline & Zuid-Limburg & Limburg & Liège & Aachen \\
& & & & \\
\hline bevolking '93 & 643.600 & 762.600 & 1.011 .000 & 1.201 .200 \\
beroepsbevolking'93 & 284.000 & 314.000 & 414.000 & 519.000 \\
beroepsdeelneming* & 63 & 60 & 62 & 63 \\
\% werkloos '93 & 9,2 & 9,0 & 11,9 & 6,7 \\
& & & & \\
structuur werkgelegenheid '92: & $2 \%$ & $3 \%$ & $2 \%$ & $3 \%$ \\
- landbouw & $38 \%$ & $38 \%$ & $29 \%$ & $37 \%$ \\
- nijverheid & $60 \%$ & $60 \%$ & $69 \%$ & $61 \%$ \\
- diensten & & & & \\
bruto reg. product & 13.700 & 16.000 & 14.900 & 14.200 \\
per inwoner '91 (ECU)** & & & &
\end{tabular}

* beroepsbevolking als percentage van de bevolking, 1993.

** gecorrigeerd voor internationale prijspeilverschillen (in koopkrachtpariteiten)

Bron: L-SEV ' 94. 


\section{De behoefte aan een informatiesysteem}

\subsection{Algemeen}

De vraag naar de behoeften aan een Informatiesysteem Onderwijs-Arbeidsmarkt, en in verband daarmee naar het mogelijke gebruik en de mogelijke actieve participatie, leverde een divers beeld op. In zeer grove lijnen waren de reacties overwegend positief in het Nederlandse deel van de Euregio. In het Belgische deel waren de reacties in het algemeen positief, maar werd sterk de aansluiting bij eigen initiatieven en activiteiten benadrukt. In het Duitse deel waren de reacties afwachtend en terughoudend. Hier moet benadrukt worden dat aan de geconstateerde verschillen geen al te absolute waarde mag worden toegekend, vooral omdat het binnen de beperkingen van een pilotstudy niet mogelijk was in alle drie landsdelen gesprekken te voeren met en informatie te verzamelen over alle relevante organisaties en instellingen. Toch kan er, mede op basis van de geraadpleegde literatuur, wel iets worden gezegd over de achtergrond van deze verschillen.

Ten eerste is er een groot verschil in de mate waarin de drie landsdelen feitelijk met mobiliteit binnen de Euregio hebben te maken. Nederlands Limburg heeft een negatief pendel-saldo met de regio Aken (8.000 à 10.000 personen volgens L-SEV 1994; ruim 4000 , waarvan $\pm 40 \%$ in Nederland woonachtige Duitsers, volgens Arbeitsamt 1993; het verschil kan liggen aan de omvangrijke 'grijze' en 'zwarte' pendel (mondelinge mededeling) en een positief saldo met Belgisch Limburg van eveneens 8.000 à 10.000 (L-SEV 1994; Van Hilst, 1994). De pendel van Duitsland naar Limburg is bijna nihil, van Limburg naar (Belgisch) Limburg gering $( \pm 700)$. De provincie Liège heeft wel een in- en uitgaande pendel met Belgisch Limburg, maar vrijwel geen pendel met Duitsland en Nederland; alleen vanuit de Ostkantons werken een aantal mensen in de regio Aken (L-SEV 1994; volgens Arbeitsamt 1993 werken ruim 2000 vanuit België in de regio Aken, waarvan $\pm 40 \%$ in België woonachtige Duitsers). Er is daarnaast een stroom leerlingen en studenten over de grenzen. Vestiging over de grens gaat vooral in de richtingen Duitsland naar Nederland en Nederland naar België. Conclusie kan zijn dat vooral de beide Limburgen te maken hebben met een relatief omvangrijke inen uitgaande pendel en vestiging over de grens, waarop de betrokken instellingen en diensten zich actief instellen; Duitsland 'ontvangt' alleen, maar lijkt mobiliteit over de grens (nog) niet als oplossing van de eigen problemen te zien. Ten tweede is er een moeilijk kwantificeerbaar, maar wel 'voelbaar' verschil in institutioneel klimaat. De betrokken Duitse instellingen lijken sterk gericht op oplossing van de problemen binnen de eigen institutionele kaders; zij wekken soms een wat bureaucratische indruk. De betrokken instellingen in Nederland lijken in het algemeen wat opener en meer georiënteerd op het omringende buitenland. In België valt vooral de pragmatische geest op, gekenmerkt door een flexibel inspelen op onmiddellijke en nabije behoeften. 
Deze verschillen in institutioneel klimaat spelen op de achtergrond mee in de wijze waarop informatie wordt verzameld, verwerkt, gebruikt en aan derden beschikbaar gesteld.

\subsection{Het beeld in Zuid-Limburg}

Alle geïnterviewden onderschreven de stelling dat een Informatiesysteem OnderwijsArbeidsmarkt voor de Euregio Maas-Rijn een toegevoegde waarde kan hebben ten opzichte van de thans reeds beschikbare informatie (zie hoofdstuk 3). Er waren wel verschillen in de relatieve waarde die men een dergelijk systeem toekende in verhouding tot bestaande informatiebronnen en de behoefte aan bepaalde onderdelen van een mogelijk systeem en aan de verschillende gebruiksmogelijkheden, maar algemeen was de indruk dat een informatiesysteem een nuttige functie zou kunnen hebben in het proces van integratie binnen de Euregio en het functioneren van diensten en instellingen binnen de Euregio.

Hieronder volgt een globaal overzicht van de reacties binnen een aantal ter zake belangrijke instellingen.

Vanuit het $R D C$ klonk duidelijk het meeste enthousiasme. Dat enthousiasme hangt samen met de taakstelling van het RDC op het terrein van studie- en beroepskeuzevoorlichting 'over de grenzen'. In veel mindere mate speelt de 'loketfunctie' van het $\mathrm{RDC}$ in het kader van de internationale diplomawaardering een rol, aangezien hiervoor een eigen informatiestructuur in het leven is geroepen (Bosker 1994). Het RDC is vooral in Duitsland intensief betrokken bij een aantal voorlichtingsprojecten; in mindere mate is er samenwerking in België. Sinds ongeveer september 1994 werkt RDCLimburg nauw samen met de PMS-centra in Belgisch Limburg en in de regio Eupen/St. Vith. De samenwerking vindt op dezelfde wijze plaats met de regio Aachen. Er is ook betrokkenheid bij samenwerkingsprojecten tussen onderwijsinstellingen. Het RDC treedt als Nederlands coördinator op van het EUREQUA-project, in het kader waarvan onder meer vier scholen voor beroepsonderwijs in Sittard, Maastricht en Heerlen samenwerken met vier vergelijkbare scholen in de regio Aachen. Vergelijkbare activiteiten zijn door COMPAZ-Groningen gestart met arbeitsämter in Niedersachen. Vooral met het oog op zijn voorlichtingsactiviteiten, maar ook op de planning en begeleiding van samenwerkingsprojecten, heeft het RDC behoefte aan informatie op Euregionaal niveau aangaande de arbeidsmarkt, in het bijzonder aan informatie over arbeidsmarktverwachtingen gegeven bepaalde opleidingskeuzes. Een ander beeld levert de 'gewone' studiekeuzevoorlichting binnen Nederland op. In het algemeen wordt hierbij tot op heden onvoldoende aandacht voor de arbeidsmarkt-relevantie van keuzes gesignaleerd; de interne procedures voorzien niet in systematische meeweging van arbeidsmarktgegevens in de voorlichtingspraktijk. De oriëntatie op grensoverschrijdende beroepsmogelijkheden is uiteraard nog beperkter. Er zijn voor wat betreft de 
voorlichtingspraktijk binnen Nederland wel initiatieven tot verbetering, zoals de LDCpublicatie 'kansen op werk' (LDC 1994). Een vergelijkbaar initiatief tot verbetering van het materiaal t.b.v. grensoverschrijdende voorlichting is er niet. In potentie is hier grote behoefte aan; een behoefte die zich steeds verder zal ontwikkelen naarmate de integratie van arbeidsmarktrelevantie in de voorlichtingspraktijk vordert en het belang van een Euregionale oriëntatie op de arbeidsmarkt toeneemt.

Wat betreft de arbeidsvoorziening bleek een verschil in informatiebehoefte tussen het management-niveau en het uitvoerend niveau. Op managementniveau is er duidelijke behoefte aan informatie over de arbeidsmarkt, zowel ten behoeve van de eigen beleidsbepaling als met het oog op het participeren in samenwerkingsverbanden binnen de Euregio. Wat betreft het laatste wordt een probleem ervaren in verband met de verschillende bestuurlijke structuur van het complex arbeidsvoorziening/studie- en beroepskeuzevoorlichting in de drie betrokken landen. In België en Nederland zijn bemiddeling en voorlichting bij gescheiden instanties ondergebracht (arbeidsbureau en VDAB/FOREM, resp. RDC en PMS-centra), in Duitsland verenigd in het Arbeitsamt. In Duitsland en België worden deze structuren centraal gestuurd, in Nederland regionaal. Deze verschillen worden als belemmerend ervaren bij het uitwisselen van relevante informatie. Een gezamenlijk informatiesysteem zou de samenwerking kunnen bevorderen; op basis van informatie die onder een gezamenlijke noemer is gebracht kunnen gezamenlijke acties worden onderbouwd. Met het oog hierop werd aangedrongen op directe bestuurlijke betrokkenheid van de betrokken instellingen bij een informatiesysteem. Inhoudelijk was er vooral interesse in de ontwikkeling van de vraagaanbodverhoudingen, en in het bijzonder in meer kwalitatieve informatie betreffende veranderingen in de werkgelegenheidsstructuur en de kwalificatievraag in verband met technologische ontwikkelingen en structuurveranderingen. Ook zou een regelmatige signalering van knelpunten op de Euregionale arbeidsmarkt van belang zijn. Het Euregionale informatiesysteem kanzo aanvullend zijn op de ontwikkeling van regionale informatiesystemen ten behoeve van de arbeidsvoorziening, zoals het regionale prognosesysteem RAMONA (Natzijl en Westra, 1993) en de voorgenomen sectorale arbeidsmarktverkenningen.

In de praktijk van de bemiddeling over de grenzen ligt de belangstelling tot op zekere hoogte anders. De diverse arbeidsbureaus zijn min of meer actief betrokken bij internationale bemiddeling en dienstverlening ten behoeve van mobiliteit over de grens. De ontwikkeling van zogenaamde Euro-loketten is afgerond; hier kunnen buitenlanders voor informatievragen en bemiddeling terecht. Aan de arbeidsbureaus in Heerlen en Maastricht zijn, mede in het kader van het EURES-project, zogenaamde Euroconsulenten verbonden. In de praktijk van de Euregionale bemiddeling is vooral informatie over openstaande vacatures van belang, naast informatie over arbeidsvoorwaarden, sociale voorzieningen e.d. Hier is tot op zekere hoogte in voorzien: uitwisseling van vacatures via terminals tussen Heerlen en Aken en schriftelijk met VDAB en FOREM; 
het EURES-netwerk (zie verder hoofdstuk 3). Ook persoonlijke contacten met collegae over de grens zijn belangrijk. Informatie op hoger aggregatieniveau betreffende vraagaanbodverhoudingen enz. wordt als achtergrondinformatie belangrijk geacht, maar de uitvoeringspraktijk voorziet thans niet in systematische kennisneming en gebruik van zulke informatie. De onmiddellijke behoefte is hier dus vooral uitbouw van de vacatureuitwisseling, met name via 'on line' verbindingen met VDAB en FOREM.

Gelieerd aan de arbeidsvoorziening zijn de Centra voor Vakopleiding Volwassenen. CV Maastricht voert in samenwerking met FOREM Liège het EURES-project 'Euroburotique' uit, een tweetalige opleiding tot secretarieel medewerker, specifiek gericht op grensoverschrijdend functioneren en leidend tot 'bi-diplomering.'

Zowel de provinciale overheid als gemeentelijke overheden hebben taken op het gebied van de arbeidsmarkt, ook op Euregionaal niveau. De provincie stelt zich als doel stimulering van een duurzame economische groei en bevordering van volledige en volwaardige werkgelegenheid, onder meer door het verminderen van discrepanties tussen vraag en aanbod. Daartoe dient de doelmatige werking van de arbeidsmarkt bevorderd te worden. Een betere informatievoorziening aangaande de arbeidsmarktverhoudingen vormt hiertoe een belangrijk middel (Provincie Limburg, 1993). Overigens is de aansluiting tussen vraag en aanbod als zodanig de verantwoordelijkheid van onderwijsinstellingen en sociale partners; de provincie heeft hier dus vooral een voorwaardenscheppende rol (Provincie Limburg, 1994). Waar het gaat om een mogelijk Euregionaal Informatiesysteem Onderwijs-Arbeidsmarkt bleek desalniettemin de nodige scepsis. Deze hield in hoofdlijn verband met vrees omtrent de mogelijke kosten, de aansluiting bij andere informatiesystemen en het gebruik in de praktijk van schriftelijke informatie en/of electronische informatiesystemen. Een informatiesysteem over de arbeidsmarkt werd van belang geacht, mits in deze bezwaren kan worden voorzien. Daarbij werd ook de mogelijkheid van informatie 'bottom up' genoemd, vanuit de belanghebbende instellingen, bedrijven enz.

Ook gemeenten voeren een actief werkgelegenheidsbeleid, veelal gericht op de specifieke knelpunten binnen de gemeente en directe omgeving (zie b.v. Gemeente Maastricht, 1993). Zeker voor een aantal grotere gemeenten in Zuid Limburg is een Euregionale oriëntatie van direct belang, in verband met de relatieve omvang van de pendel van en/of naar het aangrenzende buitenland, de vestiging van buitenlanders (vooral Duitsers) in de gemeente, de oriëntatie van bedrijven in de gemeente op export of internationaal vervoer en de vestiging van bedrijven vanuit aangrenzende landen. In dit verband is er een samenwerkingsproject tussen de grote steden in de Euregio, het MHAL-project (Maastricht, Heerlen, Hasselt/Genk, Aken en Luik), waarin onder meer het arbeidsmarktbeleid en afstemming van de scholings- en infrastructuur belangrijke aandachtspunten zijn (Gemeente Maastricht, 1993). Gezien de beperkte omvang van de gemeentelijke apparaten zou een systematische aanlevering van 
Euregionale arbeidsmarktinformatie in dit kader van groot belang kunnen zijn. Bovenstaand overzicht is niet volledig. In het kader van de pilotstudy was het niet mogelijk een aantal relevante instanties te benaderen, waaronder de Kamer van Koophandel en fabrieken, werkgevers- en werknemersorganisaties en grotere onderwijsinstellingen. De wel gevoerde gesprekken en de geraadpleegde literatuur geven echter geen aanleiding te veronderstellen dat hier een wezenlijk ander beeld naar voren zou zijn gekomen. De conclusie lijkt gerechtvaardigd dat in het Nederlandse deel van de Euregio de relevante instanties het belang van de Euregionale ontwikkeling onderschrijven, waar het gaat om de arbeidsmarkt en het onderwijs op dit vlak min of meer actief zijn en in dat verband verbetering van de informatievoorziening op z'n minst nuttig achten.

\subsection{Het beeld in (Belgisch) Limburg}

Om praktische redenen heeft de oriëntatie in het Belgische Euregiodeel vooral plaatsgevonden binnen het Nederlandstalig gebied. Waar mogelijk is geïnformeerd naar verschillen tussen de daar aangetroffen situatie en die in Liège en de Deutschsprachige Gemeinschaft. De institutionele situatie in het Belgische Euregio-deel is op een aantal punten anders dan de Nederlandse. De in verband met een Informatiesysteem Onderwijs-Arbeidsmarkt essentiële instituties op het terrein van de arbeidsvoorziening en de studie- en beroepskeuzevoorlichting zijn anders georganiseerd. De arbeidsbemiddeling wordt in het Vlaamse respectievelijk het Waalse landsdeel centraal georganiseerd in de VDAB (Vlaamse Dienst voor Arbeidsbemiddeling en Beroepsopleiding) resp. FOREM, Rijksdiensten met plaatselijke vestigingen. Studie-en beroepskeuzevoorlichting wordt verzorgd door de zogenaamde PMS-centra, onderscheiden in vrije PMS-centra (ten behoeve van het vrij (bijzonder) onderwijs) en de PMS-centra ten behoeve van het gemeenschapsonderwijs (dit is openbaar onderwijs). Belangrijk is in dit verband ook de institutionele structuur die zich heeft gevormd in verband met de economische herstructurering ofwel reconversie: Gewestelijke Ontwikkelings Maatschappij, Permanente Werkgroep Limburg en Strategisch Plan Limburg.

In 1977 is de Gewestelijke Ontwikkelings Maatschappij (GOM) Limburg opgericht. Vergelijkbare instellingen functioneren in alle Vlaamse provincies ${ }^{2}$. De GOM is een publiekrechtelijke instelling met als doelstelling de bevordering van de economische ontwikkeling van de provincie Limburg. Zij wordt bekostigd door de Vlaamse regering. Formeel hiervan onderscheiden is er de Limburgse Economische Raad LER, bekostigd door de provincie. GOM-LER functioneren in de praktijk als één organisatie. De GOM houdt zich enerzijds bezig met directe ondersteuning van het bedrijfsleven, anderzijds

2. In Wallonië is gekozen voor één gewestelijke (Waalse) ontwikkelingsmaatschappij. In de provincie Liège functioneert weleen afzonderlijk investeringsfonds, de Societé Provincial d'Investissement SPI. 
met beleidsvoorbereiding en ontwikkelingsstimulering. Belangrijke aandachtspunten zijn daarbij diversificatie van de te eenzijdige economische structuur (te afhankelijk van vooral de autoindustrie en de toeleveringsbedrijven daarvan), duurzame werkgelegenheid, stimulering van technologische ontwikkeling en bevordering van kwaliteitsbewustzijn. Activiteiten ten dienste van het bedrijfsleven omvatten onder meer het aantrekken en begeleiden van nieuwe investeringen, het begeleiden en adviseren van zowel startende als bestaande ondernemers in het midden- en kleinbedrijf, het 'Euro Info Center', dat bedrijven informeert over de gevolgen van de Europese eenwording, het bevorderen van diversificering en innovatie, bevordering van export en beschikbaarstelling van bedrijvencentra. Wat betreft het onderwijs tracht de GOM een voldoende aansluiting op de arbeidsmarkt te bevorderen. Aandachtspunten zijn daarbij de relatief lage deelname aan het hoger onderwijs ${ }^{3}$, een meer op de arbeidsmarkt gerichte studiekeuze, vooral van meisjes (Limburg kent een relatief zeer hoge werkloosheid onder vrouwen) en zorg voor een goede kwaliteit van het onderwijs. Wat betreft de beleidsmatige taakstelling is de GOM verantwoordelijk voor de voorbereiding, opstelling en bevordering van ontwikkelingsplannen. Voor de periode 1987-1997 is, met het oog op de herstructurering in verband met de sluiting van de kolenmijnen, het 'toekomstcontract voor Limburg' vastgesteld. Voor de uitvoering hiervan verkrijgt de GOM jaarlijks bij 'conventie' bevoegdheid van de Vlaamse regering. Deze bevoegdheid betreft de sanering van mijnterreinen en infrastructuur en acties in de economische en toeristische sector. De GOM heeft verder de coördinatietaak bij de uitvoering van de Europese steunprogramma's voor de regio. In 1994 is het 'integraal ontwikkelingsplan Limburg 2010' vastgesteld, dat zowel de economische, sociale als ruimtelijke ontwikkelingen betreft. De GOM heeft een sterke bestuurlijke band met de provincie; zij participeert in diverse andere verbanden als de Permanente Werkgroep Limburg, het Strategisch Plan Limburg (zie hieronder) en het Subregionaal Tewerkstellings Comitée. De GOM heeft tot slot tot taak permanente documentatie en informatie over de sociaal-economische aspecten van Limburg te verzorgen. In dat kader wordt o.m. periodiek het 'economisch rapport' uitgebracht. De GOM maakt daarbij in hoofdzaak gebruik van gegevens die zij van anderen, vooral de VDAB, aangeleverd krijgt. Zelf voert zij op beperkte schaal een enquête onder industriële bedrijven uit, o.m. naar de verwachtingen omtrent de ontwikkeling van de werkgelegenheid. Gestreefd wordt naar een meeromvattend 'arbeidsmarktobservatorium', onder meer in verband met het aandachtspunt aansluiting onderwijs-arbeidsmarkt. Gegevens over de situatie over de grens worden geregeld geraadpleegd. De GOM ontvangt regelmatig publicaties van o.m. RBA Zuid-Limburg, ETIL (L-SEV) en ROA. De beperkte vergelijkbaarheid van de statistieken stelt echter grenzen aan de bruikbaarheid. Aan een informatiesysteem dat gegevens systematisch bijeenplaatst, waar mogelijk vergelijkbaar, is duidelijk

3. De deelname aan het hoger onderwijs is in Limburg traditioneel zo'n $20 \%$ lager dan elders in Vlaanderen. De universitaire vestiging in Diepenbeek heeft hier, anders dan beoogd, geen verandering in gebracht (mededeling in interview). 
behoefte. Als mogelijke functies van een Euregionaal informatiesysteem worden genoemd:

* betere benutting van opleidingsmogelijkheden aan weerszijde van de grens; daartoe is ook inhoudelijke informatie over het opleidingsaanbod gewenst.

* bevordering van bedrijfsvestigingen: waar het gaat om vestigingen van het middenen kleinbedrijf zijn de beide Limburgen feitelijk concurrenten, maar voor grotere buitenlandse bedrijven is de grens van geen belang. Goede informatie over de mogelijkheden van de Euregionale arbeidsmarkt kan dus zeer bevorderlijk zijn. Daartoe zou een Engelstalige editie van het informatiesysteem gewenst zijn.

De GOM is geïnteresseerd in participatie in ontwikkeling en uitvoering van het informatiesysteem.

Met een enigszins vergelijkbare maar meer toegespitste doelstelling functioneert het Strategisch Plan Limburg. Deze in 1987 opgerichte organisatie is een samenwerkingsverband tussen werkgevers- en werknemersorganisaties. Doelstelling is de 'ontplooiing van Limburg tot een dynamische regio in Europa' te bevorderen. Daarbij wordt gestreefd naar een endogene ontwikkeling vanuit vooral het Limburgse midden- en kleinbedrijf. De werkwijze is overwegend praktisch en projectmatig. Scholing van zowel ondernemers als werknemers/werkzoekenden en netwerkvorming zijn belangrijke onderdelen van de activiteiten. Er is onder meer het project 'TREJO', ondersteuning van bedrijfsleiders in het midden- en kleinbedrijf door het 'peterschap' van grote bedrijven. Er worden bedrijfsgerichte cursussen verzorgd speciaal voor werkzoekende vrouwen. Tweejaarlijks wordt een beurs van toeleveringsbedrijven georganiseerd onder de titel 'Euregio-contact'. Door Strategisch Plan Limburg is een project ontwikkeld en deels uitgevoerd onder de titel 'arbeidsmarktprospectie'. Het projectplan is gericht op permanente waarneming van ontwikkelingen in het bedrijfsleven met het oog op het signaleren van bestaande en het prognosticeren van toekomstige personeelsbehoeften. De werkwijze is uiterst pragmatisch. Op basis van diverse signalen (in de pers en andere media, in rapporten van de GOM en de VDAB, personeelsadvertenties, informele contacten) worden potentieel interessante bedrijven/bedrijfssectoren, functies e.d. geselecteerd. Vervolgens wordt onderzoek gedaan door het bezoeken van individuele bedrijven. Stelregel is dat tenminste twee bedrijfsbezoeken per week plaatsvinden. Het onderzoek mondt altijd uit in een rapport richting de direct betrokkenen en zo mogelijk in concrete actie, vooral op het terrein van scholing. Inmiddels is het niet zeker of de arbeidsmarktprospectie in deze vorm wordt voortgezet; de subsidiegever van Strategisch Plan Limburg, de Permanente Werkgroep Limburg, wil het instrument opnemen in het zogenaamde arbeidsmarktobservatorium (zie hieronder). Gezien zijn betrekkelijk pragmatische taakstelling is Strategisch Plan Limburg wel geïnteresseerd in een Euregionaal Informatiesysteem Onderwijs-Arbeidsmarkt, maar worden geen mogelijkheden tot actieve participatie gezien. Voorzover de organisatie onderzoek doet staat dit altijd in dienst van de onmiddellijke actie. 
Ook de Permanente Werkgroep Limburg bestaat in verband met de reconversie. In essentie beheert deze organisatie de extra middelen ten behoeve van de economische herstructurering, vooral afkomstig uit de diverse Europese fondsen. De werkgroep is opgericht in 1987. Toen kwam het 'toekomstcontract voor Limburg' tot stand, waarin de Europese Commissie en de nationale en regionale overheden participeerden. Thans zijn de partners in PWL de Europese Commissie, de Rijks-, regionale (dit is Vlaamse) en provinciale overheid en de sociale partners. De PWL verstrekt subsidies voor onder meer opleidingen en opleidingsfondsen, voor diverse onderwijsprojecten (waaronder op het terrein van studiekeuze in het secundair (voortgezet) onderwijs), voor huisvestingsprojecten e.d. Zij treedt ook op als medefinancier van INTERREG-projecten. De PWL heeft een plan uitgewerkt voor een zogenaamde arbeidsmarkt-observatorium. Hoofddoel hiervan is een betere afstemming van de opleidingen op de arbeidsmarkt. Het geplande observatorium omvat drie hoofdelementen:

1. gegevensverzameling over de economische (sub)sectoren in de provincie;

2. gegevensverzameling over de arbeidsmarkt;

3. permanente observatie binnen de economische sectoren door 'bedrijfsprospectoren'.

Wat betreft de elementen 1 en 2: de PWL doet zelf geen onderzoek maar wil gebruik maken van de gegevens van anderen. Geconstateerd wordt dat de diverse gegevensverzamelingen te veel los van elkaar functioneren (zie ook hoofdstuk 3); daarom is het voornemen een databemiddelaar aan te stellen. De bedrijfsprospectoren zullen worden gezocht in de kring van arbeidsdeskundigen, reeds werkzaam in de sectoren. Zij moeten trends en ontwikkelingen signaleren op het vlak van te verwachten vacatures, behoefte aan kwalificaties e.d. Het plan is inmiddels goedgekeurd door de Werkgroep, maar voor de uitvoering moet nog veel worden geregeld. Streven is in juni 1995 te starten. ${ }^{4}$ Aan de ontwikkelingen op het niveau van de Euregio wordt veel belang gehecht: het is voor Limburg van groot belang zich internationaal te positioneren. Een Euregionaal Informatiesysteem Onderwijs-Arbeidsmarkt zou in dat verband van belang kunnen zijn. Ook bedrijven zouden kunnen profiteren van gerichte informatie over vacatures, opleidingsmogelijkheden e.d. binnen de Euregio. Daartoe is het wel van belang dat het informatiesysteem voor diverse gebruikers toegankelijk is. De PWL is geïnteresseerd in participatie in ontwikkeling en uitvoering van het informatiesysteem. Een mogelijkheid is daarbij dat het arbeidsmarkt-observatorium wordt benut voor de vulling van een deel van het systeem.

4. Overigens wordt ook in het 'Integraal Ontwikkelingsplan Limburg 2010' (GOM, 1994) een arbeidsmarktobservatorium aangekondigd. Aan te nemen is dat het hier om hetzelfde initiatief gaat. Het ontwikkelingsplan onderscheidt drie onderdelen binnen het observatorium: analyse van de arbeidsmarkt, screening van werkloosheid en arbeidsbemiddeling en het beroepsopleidingsaanbod. De bedrijfsprospectoren worden hier gezien als onderdeel van de analyse van de arbeidsmarkt. 
De VDAB is, evenals in Wallonië de FOREM, in 1989 ontstaan uit de Rijksdienst voor de arbeidsbemiddeling als gevolg van de regionalisatie (opdeling in Vlaanderen en Wallonië). De Rijksdienst bestaat nog steeds naast VDAB en FOREM, uitsluitend met een financiële taakstelling, nl. de verstrekking van de uitkeringen. VDAB en FOREM hebben als hoofdtaken de bemiddeling en advisering ten behoeve van werkzoekenden en vacature-aanbieders en het bieden van opleidingen in verband met de arbeidsbemiddeling. Er zijn twee hoofdvestigingen in Limburg: Tongeren en Hasselt. Naast de VDAB functioneert het Subregionaal Tewerkstellings Comitée STC met een adviserende taak richting VDAB en plaatselijke overheden. De VDAB verwerkt grote hoeveelheden gegevens betreffende de arbeidsmarkt: deels eigen gegevens betreffende werkzoekenden en vacatures, deels gegevens van anderen. Op basis van deze gegevens wordt regelmatig gepubliceerd (zie verder hoofdstuk 3 ).

Op Euregionaal niveau is de VDAB op diverse wijzen actief. $\mathrm{Er}$ is onder meer geregelde samenwerking met het arbeidsbureau in Maastricht in de vorm van (schriftelijke) uitwisseling van vacatures en gegevens over opleidingen ${ }^{5}$. Met het RDC wordt samengewerkt in een project arbeidsoriëntatie. Verder participeert de VDAB in EURES. De VDAB is geïnteresseerd in een Euregionaal Informatiesysteem Onderwijs-Arbeidsmarkt. Als mogelijke functie wordt, naast inzicht in de arbeidsmarkt, vooral genoemd inhoudelijke informatie over onderwijs en opleidingen met het oog op transparantie over de grens. Er is bereidheid tot participatie in ontwikkeling en uitvoering van een informatiesysteem.

De PMS-centra (Psycho-Medisch Sociaal Centrum) functioneren uitsluitend ten behoeve van het onderwijs. Er zijn onderscheiden centra ten behoeve van de verschillende netten ('zuilen'). ledere school wordt toegevoegd aan een bepaald centrum. Studie- en beroepskeuzeadvies geschiedt door deze centra; de scholen hebben zelf geen eigen adviseurs of decanaat. De roep om een meer arbeidsmarktrelevante studieen beroepskeuzevoorlichting is ook in Belgisch Limburg van verschillende kanten vernomen. In potentie bestaat er dus bij de centra een vraag naar ondersteunende informatie, vergelijkbaar met die bij het RDC (zie paragraaf 2.2).

Samenvattend lijkt de conclusie gerechtvaardigd dat er in Limburg een levendige interesse bestaat in iets als een Euregionaal Informatiesysteem Onderwijs-Arbeidsmarkt en een duidelijke bereidheid hieraan mee te werken. Het eigen belang bij de Euregio, de Euregionale arbeidsmarkt en de eigen positionering daarbinnen wordt duidelijk gezien. Wel is direct of indirect gewezen op potentiële problemen indien het op effectueren van samenwerking aankomt. Er is een zekere politieke spanning

5. Een 'on line' uitwisseling van vacatures, zoals tussen arbeidsbureau Heerlen en Arbeitsamt Aachen, is echter nog niet tot stand gekomen; dit terwijl de VDAB vacatures in eigen huis wel aanbiedt middels een visitekst-systeem, het Werk Informatie Systeem WIS. 
gesignaleerd, niet geheel losstaand van de verdeling van de (reconversie)middelen, die bij de uiteindelijke besluitvorming op het niveau van management en bestuur van de betrokken instellingen roet in het eten kan gooien. In dat verband is het advies naar voren gebracht de organisatie rond het informatiesysteem eenvoudig te houden en zorg te dragen voor onafhankelijkheid en een goed management.

Of de situatie in Liège afwijkt van die in Limburg is op basis van de verzamelde gegevens niet goed te beoordelen. Enerzijds zijn er grote overeenkomsten in institutionele structuur en type problematiek. Anderzijds zijn de pendelbewegingen van en naar deze provincie gering, mede als gevolg van de taalbarrière. Daaruit zou een wat geringere interesse in Euregionale zaken kunnen voortvloeien. Verdere verkenning is hier zeker nodig, waarbij overigens de provincie Liège en de semi-autonome Duitstalige gemeenschap als afzonderlijke eenheden benaderd dienen te worden.

\subsection{Het beeld in Duitsland}

In het Duitse Euregio-deel zijn belanghebbende organisaties vooral de diverse Kamers (de Handwerkskammer, de Industrie- und Handelskammer, de Landwirtschaftskammer en nog enige kleinere), het Arbeitsamt, de gemeenten, Stadt Aachen en Kreisen en de regering van Nordrhein-Westfalen. Aangezien er geen enkel bestuursniveau samenvalt met het Duitse deel van de Euregio is hiervoor een afzonderlijk orgaan gevormd, Regio Aachen.

De Kamers hebben een belangrijke rol in de regulering van het beroepsonderwijs, voorzover dat binnen het 'duale systeem' plaatsvindt (met name bij het aangaan van de leerovereenkomst en bij de examens). Zij verwerken ook gegevens over het beroepsonderwijs, waaronder het aantal leercontracten per beroep(sgroep) en het resultaat van de examens. Aangezien het overgrote deel van de leerlingen in het duaal systeem de eerste werkkring in het leerbedrijf vindt $( \pm 80 \%$, meer of minder naargelang de conjuncturele toestand -mededeling in interview-) beschikken zij over een redelijk inzicht in de aansluiting tussen beroepsonderwijs en arbeid. De Industrie- und Handelskammer geeft aan zeer geïnteresseerd te zijn in internationalisering. Gezien zijn taakstelling gaat de interesse vooral uit naar het beroepsonderwijs en de volwasseneneducatie. Prioriteit ligt daarbij bij aangrenzend Nederland en België, dus bij Limburg en de Ost-kantons. In het kader van het zogenaamde eurequa-project is het Handbuch Weiterbildung/bijscholingsoverzicht uitgegeven in het Duits en het Nederlands (IHK 1994). Deze gids bevat beknopte informatie over (vrijwel) alle opleidings- en bijscholingsinstellingen in de regio Aken, Limburg en Duitstalig België. In het kader van hetzelfde project wordt een inventarisatie uitgevoerd naar vormen van samenwerking tussen onderwijsinstellingen aan weerszijden der grens (RWTH, prof. Michielsen). De IHK maakt verder gebruik van EURES, vooral de informatie over arbeidsvoonwaarden en sociale zekerheid. Als belangrijkste knelpunt in het uitbouwen van samen- 
werking en het benutten van onderwijsmogelijkheden over de grens wordt de transparantie van opleidingen en kwalificaties gezien. Het opbouwen van een volledig overzicht van opleidingen en kwalificaties en van hun vergelijkbaarheid met Duitse pendanten zou dus zeer dienstig zijn, maar zo'n overzicht is erg arbeidsintensief en de informatie veroudert snel. Ook behoeft zo'n overzicht niet op het niveau van één Euregio te worden ontwikkeld. Andere informatie op Euregionaal niveau heeft het IHK in het kader van zijn taakstelling niet onmiddellijk nodig. Met arbeidsmarktinformatie wordt niet gewerkt omdat bemiddeling geen taak van de Kamers is doch van het Arbeitsamt. Informatie over de aansluiting onderwijs-arbeidsmarkt is voorzover het gaat om het beroepsonderwijs minder relevant omdat, zoals boven aangegeven, opleidingsplaats en eerste werkkring vrijwel samenvallen. Het algemeen belang van een goede informatievoorziening op dit terrein wordt overigens wel onderschreven.

Het Arbeitsamt verenigt de functies van arbeidsbemiddeling, studie- en beroepskeuzevoorlichting en scholing in het kader van de arbeidsvoorziening. Het Arbeitsamt is zeer geïnteresseerd in internationale mobiliteit. Dat drukt zich vooral uit in persoonlijke contacten met medewerkers van zusterorganisaties als FOREM en arbeidsbureau. Met het arbeidsbureau in Heerlen vindt wederzijdse uitwisseling van openstaande vacatures plaats via open publieksterminals (visitekst). De praktijk wijst echter uit dat Duitsland voornamelijk als ontvangend land voor grensoverschrijdende mobiliteit fungeert. De uitgaande pendel naar Nederland en België is miniem. Als oorzaken worden onder meer genoemd de taalbarrière en de gemiddeld hogere lonen (zo'n $14 \%$ hoger dan in Nederland -mededeling in interview-). De terminal van arbeidsbureau Heerlen in Aken levert nauwelijks respons op; die van Aken in Heerlen wordt frequent geraadpleegd (mededeling in interview). In het recente verleden hebben ook, in samenwerking tussen Arbeitsamt en arbeidsbureau, gerichte acties plaatsgevonden om in Limburg te werven voor beroepsgroepen met een te beperkt aanbod, zoals verpleegkundigen. De mobiliteit van en naar de andere Euregio-delen is echter, in vergelijking met die van en naar andere Länder en de migratie van buiten de EU, beperkt van omvang. Tegen deze achtergrond zijn de onmiddellijke gebruiksmogelijkheden van een Euregionaal Informatiesysteem Onderwijs-Arbeidsmarkt voor het Arbeitsamt beperkt. De dienst beschikt, op basis van eigen cijfermateriaal, over betrekkelijk uitgebreide arbeidsmarktinformatie (zie verder hoofdstuk 3). Daarenboven worden de publicaties van zusterorganisaties als FOREM, VDAB en RBA verzameld. Desalniettemin wordt wel een toegevoegd nut van een mogelijk informatiesysteem gezien, met name op de punten:

* De ontwikkeling van de werkgelegenheid in de aangrenzende Euregio-delen, in verband met het scholingsbeleid en het verkennen van plaatsingsmogelijkheden. Daartoe is wel een regelmatige signalering en een laag aggregatieniveau vereist.

* Informatie over de inhoud van opleidingen en kwalificaties en ontwikkelingen daarin. 
De gemeentelijke overheden en de landsoverheid (Stadt Aachen, kreisen, landesregierung) zijn in dit verband vooral van belang in verband met hun verantwoordelijkheden voor het algemeen onderwijs, het beroepsonderwijs in schoolverband en het hoger onderwijs en in verband met beleid betreffende bevordering van werkgelegenheid en ontwikkeling van de economische structuur. Er is geen gelegenheid geweest deze bestuursorganen te benaderen; in de literatuur zijn geen gegevens aangetroffen aangaande hun betrokkenheid bij de ontwikkelingen in de Euregio, maar aan te nemen is dat deze betrokkenheid wel bestaat.

Een bijzondere positie neemt Regio Aachen in. Deze organisatie is gevormd als Duitse 'poot' van de Euregio, aangezien het Duitse deel van de Euregio zich over meerdere bestuurlijke eenheden uitstrekt. Het bestuur wordt uitgeoefend door het Land, de gemeentelijke overheden (Kreisen en Stadt Aachen), de Kamers en de werkgevers- en werknemersorganisaties. Regio Aachen coördineert de Duitse inbreng in de Euregio en treedt als contactpunt op voor INTERREG-projecten. Ook Regio Aachen noemt als meest concreet belang van een Euregionaal informatiesysteem de ondersteuning van activiteiten op onderwijsterrein: uitwisseling van leerlingen, werving van leerlingen over de grens en vormgeving van kleine en dure opleidingen op Euregionaal niveau, met het oog op efficiënte benutting van middelen. In het algemeen onderwijs gaat het vooral om uitwisseling, stages over de grens en Nederlands als vak. Belangstelling hiervoor is er vooral in de gebieden die direct aan België en Nederland grenzen; in verder weg gelegen delen van de regio als Düren is die belangstelling er nauwelijks. Als mogelijk geïnteresseerden in een informatiesysteem op Euregionaal niveau worden dus, naast de Kamers en het Arbeitsamt, vooral de onderwijsautoriteiten gezien. Voor wat betreft het schools onderwijs zijn dat de gemeenten. Scholen hebben een zekere initiatiefruimte, vooral op het vlak van uitwisseling van leerlingen e.d., maar zodra er geld voor nodig is, toewijzing van personeel in het geding is (Nederlands als vak) of aanpassing van regelgeving aan de orde is zijn de gemeenten bepalend. Ook regio Aachen acht informatie over inhoud en vergelijkbaarheid van opleidingen en kwalificaties de hoogste prioriteit. Het gebrek aan transparantie is vaak de beperkende factor bij samenwerkingsprojecten.

Samenvattend lijkt de conclusie gerechtvaardigd dat de opstelling tegenover een mogelijk Euregionaal Informatiesysteem Onderwijs-Arbeidsmarkt in het Duitse Euregiodeel in het algemeen niet afwijzend maar wel passief en afwachtend is. Men is geïnteresseerd, maar de bereidheid tot actieve participatie is voorshands gering. Vanuit de positie van 'ontvangend land' ziet men het meeste belang bij inhoudelijke informatie over onderwijs en opleidingen met het oog op waardering van inkomende mobiliteit en uitwisseling van leerlingen e.d.; aan Euregionale arbeidsmarktinformatie wordt minder waarde gehecht. 


\subsection{Het Euregio-bestuur}

De Euregio wordt gedragen door een stichting volgens Nederlands recht, gehuisvest in het Gouvernement te Maastricht. Het bestuur wordt uitgeoefend door de verantwoordelijke besturen van de vijf partner-regio's (provincies Limburg, Limburg en Liège, duitstalige gemeenschap, Land Nordrhein-Westfalen). Aan de stichting is een klein bureau verbonden, bestaande uit gedetacheerde ambtenaren vanuit de vijf verantwoordelijke besturen en een kleine ambtelijke staf. Eén der gedetacheerde ambtenaren oefent steeds voor twee jaar het coördinatorschap uit. Aan de stichting, dus aan de Euregio, is in formele zin geen bestuursbevoegdheid gedelegeerd. De stichting coördineert en adviseert, maar besluitvorming en uitvoering is voorbehouden aan de verantwoordelijke besturen. De activiteiten vanuit de stichting zijn ondergebracht in twee jaarprogramma's, het sociaal-economische en het sociaal-culturele, beide bekostigd uit bijdragen van de besturen en het fonds INTERREG. De activiteiten zijn gegroepeerd rond samenwerkingsthema's; voorwaarde is steeds samenwerking over de grenzen heen. Een samenwerkingsthema binnen het sociaal-culturele programma is dat van onderwijs, beroepsonderwijs en volwasseneneducatie. Hier vallen zeer uiteenlopende activiteiten onder, zoals netwerkvorming schoolleiders, taalseminars, ontwikkeling van gemeenschappelijke leerplannen bedrijfsmanagement en 'arbeidspedagogie' en een project 'tri-diplomering' voor de opleiding afwerkingstechnieken

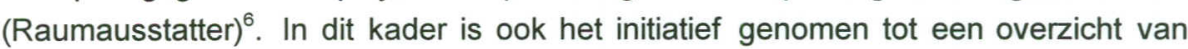
specifiek beroepsgerichte opleidingen in de hele Euregio, in uitbreiding op het Handbuch Weiterbildung/bijscholingsoverzicht van de IHK (zie par. 2.4). Het RDC voert thans een haalbaarheidsonderzoek uit, vooral gericht op de beschikbaarheid van gegevens voor dit overzicht. De stichting, i.c. het bureau, verzamelt zelf geen gegevens over de Euregionale arbeidsmarkt en het onderwijs. De thema's arbeidsmarkt en werkloosheid hebben echter wel hoge prioriteit binnen het geheel der activiteiten. In dat verband wordt het mogelijke belang van een Euregionaal Informatiesysteem Onderwijs-Arbeidsmarkt groot geacht, vooral met het oog op bevordering van grensoverschrijdende mobiliteit, ondersteuning van arbeidsmarktrelevante studie- en beroepskeuze en transparantie van het onderwijs- en opleidingsaanbod.

\subsection{Resumerend: de potentiële vraag}

De kernvraag in dit hoofdstuk is voor welke (typen of groepen) instanties en/of personen een informatiesysteem welke functies kan vervullen. Antwoord op deze vraag dient in hoge mate sturing te geven aan de ontwikkeling van een systeem. In het voorgaande is gepoogd hiervan een globaal beeld te geven per Euregio-deel. In deze

6. Dit project wordt uitgevoerd door de stichting EB (Europese Beroepsopleidingen), een samenwerkingsverband van twee Nederlandse, een Duitse en een Belgische school. RDCLimburg is als adviseur bij dit project betrokken. 
resumerende paragraaf wordt echter van deze nationale verschillen geabstraheerd, zodat conclusies mogelijk zijn aangaande het type informatiesysteem dat aan zou kunnen sluiten op de verschillende typen gebruik. Daarbij spelen ook veronderstellingen aangaande potentiële behoeften aan informatie, de ervaring met andere informatiesystemen (b.v. het POA-systeem van het ROA) en algemene inzichten omtrent bestuurlijke informatievoorziening een rol.

In onderstaand overzicht zijn de gebruikersgroepen tentatief geordend naar de mate waarin zij (in potentie) een meer danwel minder direct belang hebben bij een Euregionaal informatiesysteem onderwijs -arbeidsmarkt.

1. De arbeidsvoorziening: heeft op management-niveau vooral behoefte aan informatie ten behoeve van de bepaling van het beleid bij de bemiddeling, in het bijzonder bemiddeling over de grens: actuele en verwachte tekort-sectoren, succesverwachtingen ten aanzien van werkzoekenden met specifieke kwalificaties e.d.. Regelmatige signalering van knelpunten in de vraag-aanbod verhoudingen staat centraal. Ook is informatie van belang voor de bepaling van het scholingsbeleid, i.h.b. afstemming van het scholingsaanbod op de actuele en voorziene vraag en op technologische en organisatorische ontwikkelingen in het beroepsleven. Dat vergt regelmatig gepubliceerde informatie op betrekkelijk laag aggregatieniveau, zowel waar het gaat om de opleidingsachtergrond, het soort vraag als de voorziene kwalitatieve ontwikkelingen. Een andere in alle drie Euregiodelen gehoorde vraag is die naar inhoud en civiel effect (kwalificaties) van onderwijs en opleidingen. Op uitvoerend niveau is er vooral behoefte aan afronding en vervolmaking van de 'on line' uitwisseling van vacatures.

2. Studie- en beroepskeuzevoorlichting: heeft vooral informatie nodig om adequaat te kunnen voorlichten over de richting van en kansen bij bepaalde keuzes op het vlak van studie en beroep. In de praktijk blijkt het moeilijk verwachtingen aangaande kansen op de arbeidsmarkt te integreren in de voorlichting voor en de begeleiding van studieen opleidingskeuzen. Dit terwijl er een toenemende druk is tot meer arbeidsmarktrelevante keuzes. Bij internationalisering in de voorlichting en begeleiding is het nog moeilijker relevante informatie over de arbeidsmarkt te integreren. Hetzelfde geldt bij voorlichting aan en begeleiding van buitenlanders. Het informatiesysteem zou hier een belangrijke ondersteunende functie kunnen hebben. Ook hier zou dat betekenen regelmatige publicatie en een laag aggregatieniveau; de nadruk zou vooral op prognoses moeten liggen en het aanreiken van een interpretatiekader ten behoeve van de voorlichtingspraktijk zou dienstig zijn. Bovendien is er ook hier vraag naar informatie over inhoud en civiel effect van onderwijs en opleidingen over de grens.

3. Intermediaire organen ten behoeve van de arbeidsmarkt en de economische ontwikkeling en -herstructurering, zoals de diverse Kamers en de ontwikkelingsmaatschappijen, hebben vooral belang bij informatie die hun activiteiten direct 
ondersteunen. Voor een deel vallen deze activiteiten samen met die van gebruikersgroepen die elders in dit overzicht worden genoemd (b.v. regulering van het beroepsonderwijs -Duitse Kamers-, verzorgen van opleidingenaanbod -GOM-), voor een deel zijn dit beleidsmatige, stimulerende en coördinerende activiteiten gericht op verbeterde werking van de arbeidsmarkt en versterking van de economische structuur. Ten behoeve van deze taakstelling is een betrekkelijk uitvoerige informatievoorziening dienstig ten aanzien van alle aspecten van de Euregionale arbeidsmarkt en de aansluiting onderwijs-arbeidsmarkt. Deze informatie moet bovendien 'op afroep' kunnen worden gespecificeerd voor sectoren, regio's enz. waar zich actuele ontwikkelingen voordoen. De betrokken organisaties beschikken met dit doel over het algemeen zelf over documentaire voorzieningen, maar hun documentatie is grotendeels niet op Euregionaal niveau ingericht. Een Euregionaal Informatiesysteem Onderwijs-Arbeidsmarkt kan voor dit type instellingen dus een belangrijke toegevoegde waarde hebben.

4. Onderwijsinstellingen, onderwijsautoriteiten: er zijn verschillen in de beleidsruimte van afzonderlijke onderwijsinstellingen en de gemeentelijke, regionale/provinciale en nationale onderwijsautoriteiten. Globaliter is in Nederland de beleidsruimte van afzonderlijke onderwijsinstellingen groot, binnen meer of minder gedetailleerde voorschriften van de nationale overheid; in België en Duitsland is meer beleidsruimte, ook op leerplanniveau, gelegd bij autoriteiten op nationaal niveau (Waalse en Vlaamse gemeenschappen en de zogenaamde onderwijsnetten; de Länder) en op gemeentelijk niveau. Ook de positie van 'intermediaire organen' als Industrie- und Handelskammer, landelijke organen beroepsonderwijs enz. is heel verschillend. Ongeacht de verschillen in het niveau waarop besluitvorming in het onderwijs tot stand komt kan informatie hier vooral van belang zijn voor de planning van het onderwijs- en scholingsaanbod in relatie tot (voorziene) vraag op de arbeidsmarkt. Het kan daarbij gaan om planning van cursusaanbod mede in relatie tot verwachte vraag aan weerszijden van de grenzen, om de inrichting van cursussen met het oog op grensoverschrijdende kwalificatie (b.v. zogenaamde bi- en tridiplomering en euro-kwalificatie) en om concentratie van bepaald onderwijs- en scholingsaanbod voor de hele of gedeelten van de Euregio. Meer in het algemeen kan het informatiesysteem de internationalisering, en in het bijzonder de Europese en Euregionale oriëntatie, van het onderwijs bevorderen. Onderwijsinstelling hebben dus vooral belang bij periodieke informatie op laag aggregatieniveau betreffende de vraag, in het bijzonder prognoses. Misschien is voor het onderwijs een laag aggregatieniveau voor wat betreft de regionale component (woonplaats e.d.) van extra belang, vooral op de lagere onderwijsniveaus. De benodigde prognosetermijn is afhankelijk van de duur van de opleiding (2 à 5 jaar). Verder kunnen onderwijsinstellingen belang hebben bij signalering van kwalitatieve ontwikkelingen, zowel met het oog op de ontwikkeling van de onderwijsinhoud als ten behoeve van de planning van het cursusaanbod. 
5. Werkgevers(organisaties), zowel in de publieke als in de private sector. hebben vooral behoefte aan informatie in verband met het wervings- en scholingsbeleid. In Euregionaal verband is vooral van belang dat de mogelijkheden voor werving van bepaalde categorieën werknemers over de grens worden getoond. Informatie over verwachte technologische ontwikkelingen en verwachte (arbeids)marktverhoudingen kan echter ook een activerende en stimulerende functie hebben. Het biedt bedrijven extra mogelijkheden in te spelen op de gunstige mogelijkheden van de Euregio Maas Rijn. Werkgevers hebben dus, naast een wat globale signalering van ontwikkelingen op de arbeidsmarkt, vooral belang bij regelmatige informatie op laag aggregatieniveau betreffende het beschikbare arbeidsaanbod in de Euregio. Verder kunnen zij profiteren van regelmatige kwalitatieve signalementen van ontwikkelingen in de werkgelegenheidsstructuur, technologische ontwikkelingen e.d.. Een ander aspect is informatie over de aanbodzijde van de Euregionale arbeidsmarkt ten behoeve van in vestiging geïnteresseerde grote (buitenlandse) bedrijven met een groot wervingsgebied. Waarschijnlijk kan hierin het beste worden voorzien van geval tot geval, waarbij informatie wordt geselecteerd en gepresenteerd ten behoeve van de gegadigde (selectie naar relevante sectoren en opleidingssegmenten, taal van de presentatie e.d.). Het Euregionale informatiesysteem kan in deze gevallen ondersteunend zijn voor samenwerking bij het binnenhalen van grote bedrijfsvestigingen.

6. Beleidsinstanties op landelijk, provinciaal en gemeentelijk niveau: de informatiebehoefte van beleidsinstanties is waar het gaat om de arbeidsmarkt over het algemeen tamelijk globaal. Overheden houden zich met informatievoorziening bezig met het oog op de eigen taakuitoefening en als dienstverlening aan, c.q. voorwaardelijke activiteit voor het functioneren van, burgers en andere instanties. Waar het gaat om de eigen informatievoorziening betreft het vooral de functies van monitoring, evaluatie en beleidsvoorbereiding. De functie van monitoring, dit is permanente waarneming en bewaking, is vooral gericht op het tijdig signaleren van mogelijke knelpunten, die aanleiding kunnen zijn tot beleid. De voorbereiding van dat beleid moet vervolgens met informatie worden onderbouwd. Waar in het kader van beleidsvoorbereiding of evaluatie nodig moet meer specifieke informatie kunnen worden gegenereerd. Informatieverstrekking als dienstverlening vindt vooral plaats in de vorm van publicatie. De betrokkenheid van de overheidsinstanties op de diverse niveaus binnen de Euregio bij de verschillende onderdelen van het onderwijs- en arbeidsmarktbeleid is verschillend, in relatie tot verschillen in de zeggenschapsverhoudingen zowel tot de nationale overheden als tot intermediaire en private instellingen. Rekening houdend met deze verschillen zou een informatiesysteem ten behoeve van gebruikers op overheidsniveau vooral aan de volgende kenmerken te voldoen:

* globale cijfers, met de nadruk op uitkomsten, prestaties e.d.;

* periodiek te publiceren;

* mogelijkheid van nadere bevraging ten behoeve van specifieke evaluatie en beleidsvoorbereiding. 
7. Euregionale instanties en autoriteiten: de Euregio Maas-Rijn is als zodanig geen bestuurlijk niveau; zij heeft geen bevoegdheden in publiekrechtelijke zin en geen eigen budget als basis voor sturing. De Euregio is echter wel een belangrijk coördinatieforum en platform voor initiatieven en adviezing gericht op de verantwoordelijke besturen en betrokken organisaties. Coördinatie, initiatief en advisering kunnen in potentie worden ondersteund door een Euregionaal informatiesysteem. Op het niveau van de Euregio hebben zich diverse meer en minder formele netwerken gevormd, onder andere van werkgevers- en werknemersorganisaties en van instanties op het gebied van arbeidsvoorziening en studie- en beroepskeuzevoorlichting. Deze netwerken beschikken niet over eigen mogelijkheden voor informatievoorziening; zij zijn dus in potentie gebaat bij een informatiesysteem dat hun totale werkterrein bestrijkt. Een informatiesysteem op Euregionaal niveau kan, zoals door verschillende geïnterviewden is opgemerkt, een belangrijke integrerende functie hebben, enerzijds door betrokkenheid bij de ontwikkeling en vulling ervan, anderzijds doordat het als grondslag kan dienen voor gezamenlijke probleemverkenning en -signalering en voor gezamenlijke actie.

8. De openbaarheid: los van en buiten genoemde instanties zijn velen geïnteresseerd in ontwikkelingen op de arbeidsmarkt. Problemen op de arbeidsmarkt raken dan ook de positie van velen. Informatie op Euregionaal niveau kan daarenboven van groot belang zijn voor de acceptatie van het verschijnsel 'Euregio' en voor de mogelijkheden die deze biedt. Verspreiding van informatie met deze functie geschiedt vooral via de publieke media. Toegankelijkheid van een informatiesysteem voor de media en voor geïnteresseerde leken is dus van groot belang. 



\section{De beschikbaarheid van gegevens}

\subsection{Algemeen}

De pilot-study betreft de wenselijkheid en de mogelijkheid van een informatiesysteem onderwijs-arbeidsmarkt ten behoeve van de Euregio Maas-Rijn. In hoofdstuk 2 is vooral de wenselijkheid verkend. In dit hoofdstuk staat vooral de mogelijkheid voorop: zijn de benodigde gegevens beschikbaar? Het gaat daarbij om een aantal deelvragen:

* over welke entiteiten zijn in ieder landsdeel welke gegevens voorhanden ?

* (verschillen in) aggregatieniveau van deze gegevens, (verschillen in) classificatie.

* ruimtelijk niveau waarop de gegevens beschikbaar zijn: beschikbaar op c.q. desaggregeerbaar naar het niveau van de Euregio-delen, eventueel naar nog kleinere eenheden?

* vorm van de gegevens: schriftelijke versus electronische bestanden, ruwe bestanden versus geaggregeerde, wel of niet gepubliceerde informatie e.d.

* beschikbaarheid van de gegevens: technische, financiële en privacyrechtelijke beperkingen aan de beschikbaarstelling.

In de loop van de pilotstudy is voor de meeste Euregio-delen (uitgezonderd provincie Liège en de Ostkantons) zowel betreffende onderwijs als arbeidsmarkt materiaal verzameld dat betrekkelijk gedetailleerde antwoorden op deze vragen mogelijk maakt. Desondanks is het materiaal zelfs voor de onderzochte Euregio-delen nog niet volledig. Voor beantwoording van de globale haalbaarheidsvraag is die volledigheid evenwel niet noodzakelijk.

In dit rapport wordt alleen een globaal beeld geschetst van de haalbaarheid; de details worden bewaard voor de eventuele ontwikkeling van de informatieproducten.

Het overzicht is ingedeeld naar de vier elementen van een informatiesysteem die in de probleemstelling worden genoemd respectievelijk uit de behoeftenpeiling (hoofdstuk

2) sterk naar voren komen:

* de Euregionale arbeidsmarkt

* aansluiting onderwijs-arbeidsmarkt

* kwalitatieve signalementen

* informatie over onderwijs en opleidingen. 


\subsection{De Euregionale arbeidsmarkt}

\section{Het Duitse Euregio-deel}

Telgegevens aangaande de arbeidsmarkt in strikte zin zijn betrekkelijk volledig, op laag aggregatieniveau voor wat betreft beroep(sgroep), betrekkelijk actueel en zonder bijzondere beperkende voorwaarden verkrijgbaar bij het Arbeitsamt en het Institut für Arbeit und Beruf in Nürnberg. Het gaat in hoofdlijn om aantallen betreffende de beroepsbevolking, de beroepsbevolking in loondienst (sozialversicherungspflichtig), arbeidslozen, gemelde vacatures, geslaagde bemiddelingen, deelname aan specifieke (van het Arbeitsamt uitgaande) opleidingen en tewerkstelling in werklozenprojecten (Arbeitsbeschaffungsmassnahmen). De gegevens zijn beschikbaar naar geslacht en nationaliteit. Geografisch is in ieder geval een onderscheid naar de verschillende rayons (Arbeitsamtbezirke) mogelijk. Er zijn bepaalde beperkingen, b.v. ten aanzien van kleine deeltijdbanen.

De nationale statistiek (Statistisches Bundesamt, 1994) bevat globale gegevens over de onderwijsachtergrond van de werknemers en van de bevolking als geheel en over de beroepsbevolking als geheel naar sector en beroepsgroep. Deze gegevens zijn deels afkomstig uit de volkstelling (Mikrozensus). Nadeel van deze gegevensbron is dat de verwerking veel tijd in beslag neemt (in 1994 cijfers uit 1991). Of gegevens over de onderwijsachtergrond in meer detail en/of op regionaal niveau kunnen worden afgeleid kon niet worden nagegaan. In ieder geval lijkt de 'Ausbildung' van de werkzame 'Fachkräfte' bekend op het regionaal niveau van de Länder (Bundesanstalt für Arbeit, 1993).

Gegevens over het onderwijs zijn beschikbaar bij de gemeenten en het Landesamt voor wat betreft het algemeen onderwijs, het beroepsonderwijs in schoolverband en het hoger onderwijs, en bij de Kamers voor wat betreft het beroepsonderwijs in het duale systeem. De landelijke statistiek (Statistisches Bundesamt, 1994) presenteert onder meer de aantallen schoolverlaters naar schoolsoort en diplomabezit en wat betreft het beroepsonderwijs de aantallen leerlingen, nieuwe leerovereenkomsten en behaalde diploma's. Het gaat hierbij om rechte tellingen. Voorzover bekend is er geen matrix- of stroomstatistiek, hetgeen beperkingen oplevert voor het gebruik in prognoses van de arbeidsmarkt-instroom van schoolverlaters. De gegevens ten aanzien van het beroepsonderwijs zijn geordend naar de 'erkende opleidingsberoepen', dus betrekkelijk gedetailleerd. Van de beroepsopleidingen is de vooropleiding als instroomkenmerk bekend.

Van potentieel groot belang is het voorstel van het Institut für Arbeitsmarkt- und Berufsforschung tot ontwikkeling van een systeem ten behoeve van de analyse van regionale arbeidsmarkten, het zogenaamde REGARIS-project. Dit systeem zou zowel 
een monitor-functie hebben (zogenaamde Regionalprofilen op basis van indicatoren) als prognoses van arbeidsvraag en -aanbod en analysemodulen moeten omvatten. Volgens voornemen zal dit project eind 1995 worden afgerond. 'Regio Aachen' kan binnen het voorgenomen systeem zichtbaar worden gemaakt; daarmee zou een aanzienlijk deel van de informatievraag betreffende dit Euregio-deel kunnen worden gedekt.

Prognoses ten aanzien van de vraag en/of het aanbod zijn niet aangetroffen. De Bundesanstalt für Arbeit uit methodologische bedenkingen ten aanzien van prognoses (Bundesanstalt für Arbeit, 1993), en stelt in de plaats daarvan "Beschäftigungsaussichten .... durch differenzierte statistische Daten" ofwel de "Prämisse ... dass es möglich sei, aus Struktur-, Entwicklungs- ud Mobilitätsdaten Aussagen über ausbildungs- und berufsspezifische Beschäftigungschancen und -Risiken abzuleiten" (ibidem). Daarbij wordt uitgegaan van het 'ervaringsfeit' dat structuurveranderingen zelden abrupt optreden, integendeel zijn gebaseerd op langetermijn trends. Tegenover deze opstelling van de Bundesanstalt staat die van het IAB, dat prognoses ontwikkelt in het kader van het eerdergenoemde REGARIS-project.

De aggregatie van de gegevens naar beroep(sgroep) is in Duitsland anders dan in Nederland, maar als gevolg van de levering van gegevens aan EUROSTAT ten behoeve van onder meer de Labour Force Survey zijn gegevens ook in de internationale codering beschikbaar. Of deze echter ook op het geografisch niveau van het Euregio-gebied kunnen worden geleverd is echter niet waarschijnlijk.

\section{Belgisch Euregiodeel, in het bijzonder Limburg}

België wordt in het algemeen gekenmerkt door een enigszins chaotisch beeld waar het de statistische informatievoorziening betreft (Dejonckheere, 1994). Waar het gaat om de diverse aspecten van de arbeidsmarkt moeten relevante gegevens uit diverse databronnen worden gecombineerd. Daarbij zijn er verschillen in classificaties, termijnen waarop gegevens beschikbaar komen en voorwaarden voor beschikbaarstelling. Een algemene klacht is de trage verwerking van veel gegevens; de gegevens aangaande het Belgische Euregio-deel zullen dus deels iets achterlopen op die der andere Euregio-delen. Er zijn echter meerdere creatieve en pragmatische initiatieven aangetroffen om te voorzien in het "nationaal statistisch deficit". In dit verband zijn vooral van belang de verschillende initiatieven en projecten tot databemiddeling, gericht op het leveren van relevante statistiek uit de diverse beschikbare bronnen. Deze initiatieven zijn zowel in Limburg aangetroffen (m.n. het plan tot aanstelling van een databemiddelaar door de Permanente Werkgroep Limburg) als op regionaal (dit is Vlaams) niveau (het steunpunt Werkgelegenheid, Arbeid en Vorming WAV, een samenwerkingsverband tussen drie onderzoeksinstellingen te Leuven). De algemene indruk is dat alle relevante arbeidsmarktgegevens ten aanzien van het Belgisch 
Euregiodeel, onderscheiden naar de beide betrokken provincies, geleverd kunnen worden, zij het met een zekere vertraging. Wat betreft de werkgelegenheid zijn zeer gedetailleerde gegevens beschikbaar in de databanken van de instellingen voor uitvoering van de sociale zekerheid (RIZIV, RSZ, RSVZ). Grootste problemen zijn hier verschillen in classificatie en vooral de trage verwerking van de administratieve gegevens. Er zijn overigens initiatieven tot verbetering. Een belangrijke is het streven naar aanlevering van de RSZ-gegevens door de werkgevers op electronische drager en het opbouwen van een daarop gebaseerde databank met individuele loon- en arbeidstijdgegevens (LATG). Hierop zijn in principe zeer gedetailleerde analyses mogelijk, al zullen de kosten en de benodigde rekencapaciteit voor het bewerken van deze mega-bank beperkingen opleggen. Voorlopig echter is de bank nog niet gereed; zo'n $20 \%$ van de werkgevers (voornamelijk de kleinere bedrijven) levert nog schriftelijk aan (Dejonckheere en Timmerman, 1994). Wat betreft de werkloosheid, de arbeidsbemiddeling en de opleidingen in het kader van de arbeidsbemiddeling verzamelt de VDAB gedetailleerde gegevens. Deze worden opgenomen in een landelijke databank, het SIMONA-systeem. De publicatie van deze gegevens is betrekkelijk actueel. Voordeel is hier dat de gegevens direct door de vestigingen in het Euregiodeel (Tongeren en Hasselt) geleverd kunnen worden. De statistiek betreffende het onderwijs betreft voorzover bekend alleen rechte tellingen; er zijn geen matrix- en stroomgegevens. Ook hier vormt dat een beperking op het gebruik voor prognoses. Prognoses worden door verschillende instanties opgesteld. Het Integraal Ontwikkelingsplan Limburg bevat prognoses van de beroepsbevolking en de arbeidsmarktvraag. Vormen van prognoses worden ook opgesteld door o.m. de SociaalEconomische Raad voor Vlaanderen (SERV), de Algemene Planningsdienst en de Nationale Bank (conjunctuuronderzoeken). Een probleem kan vooral de prognose van het arbeidsmarktaanbod zijn.

\section{Zuid-Limburg}

Nederland beschikt in het algemeen over een uitgebreide en krachtige statistische informatievoorziening. Probleem is hier wel dat de meeste statistiek landelijk wordt opgebouwd. Verzameling van gegevens betreffende, in dit geval, Zuid Limburg betekent voor een groot deel desaggregatie van landelijke gegevens; dit blijkt niet voor alle relevante databronnen (volledig) mogelijk. Door het ROA zijn de mogelijkheden om, door enerzijds desaggregatie van landelijke gegevens en anderzijds aanvulling vanuit regionale databronnen, tot betrekkelijk volledige uitspraken op regionaal niveau te komen reeds eerder verkend (onder meer De Grip 1991 en De Grip 1993). Conclusie is dat dit tot op grote hoogte mogelijk is. De uitspraken die landelijk kunnen worden gedaan op basis van het informatiesysteem onderwijs -arbeidsmarkt POA zijn voor een groot deel ook regionaal mogelijk, zij het soms op wat hoger aggregatieniveau. Eenvoudige (niet gecombineerde) gegevens over beroepsbevolking, arbeidsmarktaanbod, werkloosheid, vacatures, bemiddeling en scholing in het kader 
van de arbeidsvoorziening kunnen daarnaast op gedetailleerd niveau worden gepresenteerd. Een belangrijke nieuwe ontwikkeling is het operationeel worden van een arbeidsmarktmodel op regionaal niveau voor de arbeidsvoorziening RAMONA (Natzijl en Westra, 1993), ondersteund door een prognosemodel voor het regionaal arbeidsaanbod (Buist, van Gils en Vermeulen, 1993). De uitkomsten zijn wel op een betrekkelijk hoog aggregatieniveau. Ook is hier van belang het eerdergenoemde initiatief van RBA Zuid-Limburg voor een project sectorale arbeidsmarktverkenningen. Het gaat hier om een regelmatige monitoring van de arbeidsmarkt-sectoren op basis van secundaire analyse van aanwezig materiaal en regelmatige expert-meetings.

Het ETIL is een onderzoeksinstelling met banden met de provincie, een aantal gemeenten en de Kamers van Koophandel en Fabrieken. In het kader van zijn basisactiviteiten verzamelt het ETIL sociaal-economische gegevens voor Limburg, in ieder geval op het niveau van de COROP-gebieden (Noord-, Midden- en Zuid-Limburg), die vergelijkbaar zijn met Nederland als geheel. Over de resultaten wordt jaarlijks in hoofdlijn gerapporteerd in de Limburgse Sociaal-Economische Verkenningen, de L-SEV. Meer gedetailleerde gegevens, waaronder gegevens over de Euregio Maas-Rijn en deelgebieden daarbinnen, kunnen tegen vergoeding worden geleverd.

\subsection{De aansluiting onderwijs-arbeidsmarkt}

Gegevens over de overgang van het onderwijs naar de arbeidsmarkt en het succes op die arbeidsmarkt (snelheid van vinden van werk, duur van de eerste aanstelling, loonniveau, aansluiting van de vooropleiding op de -eerste- aanstelling e.d.) hebben binnen een Informatiesysteem Onderwijs-Arbeidsmarkt een tweeledige functie. Enerzijds bieden zij een belangrijke aanvulling op de arbeidsmarkt-gegevens als zodanig (zie boven). Waar het gaat om b.v. de vraagkant geven de vacatures maar een beperkt beeld (onder meer Muysken e.a., 1994); de feitelijke opname van schoolverlaters en de meer of minder opleidingsspecifieke opname bieden krachtige aanvullende informatie. Anderzijds zijn de gegevens op zich van belang als belangrijk middel tot evaluatie van het onderwijs in relatie tot de arbeidsmarkt. Op het niveau van de Euregio zijn daarbij specifieke vragen aan de orde betreffende verschillen tussen het beeld in de Euregio-delen en de respectieve landelijke uitkomsten ${ }^{7}$ en betreffende verschillen en overeenkomsten in doorstroompatroon tussen de Euregio-delen.

Systematisch herhaald onderzoek naar de overgang onderwijs-arbeidsmarkt wordt alleen in Nederland gedaan, het zogenaamde RUBS-onderzoek. Met een beperkte ophoging van de steekproef binnen de regio kunnen dezelfde uitspraken als op

7. Zo is in (Belgisch) Limburg nog steeds een onderwijsachterstand aanwijsbaar ten opzichte van de situatie in heel Vlaanderen (Gewestelijke Ontwikkelingsmaatschappij, Integraal Ontwikkelingsplan 1994). 
landelijk niveau worden gedaan op het niveau van Zuid-Limburg. In België is dit type onderzoek incidenteel uitgevoerd voor bepaalde gebieden en voor bepaalde onderwijssoorten (Denys, 1991; Switten, 1994). Het steunpunt WAV werkt echter, in opdracht van de Vlaamse regering en het VESOC, aan een scenario voor een met het RUBS vergelijkbaar periodiek onderzoek; dit zou kunnen worden opgebouwd uit regionale componenten, uit te voeren door onderzoeksinstellingen in de betreffende regio, i.c. Limburg (mededeling in interview). Dit onderzoek zou mede in het kader van het Euregionaal Informatiesysteem Onderwijs-Arbeidsmarkt kunnen worden uitgevoerd. In Duitsland wordt geen systematisch herhaald onderzoek op dit terrein uitgevoerd. De informatiebehoefte op dit punt wordt voor wat betreft het beroepsonderwijs gedeeltelijk ondervangen doordat de leerlingen (waarvan gegevens zijn) in zo'n 90\% van de gevallen in het opleidingsbedrijf werkzaam blijven. Gegevens over de situatie enige tijd na beëindiging van de opleiding, over de ervaren aansluiting e.d. ontbreken echter. Desalniettemin zijn deze cijfers voor het Euregionaal systeem bruikbaar. Wat betreft het algemeen onderwijs verzamelen afzonderlijke scholen waarschijnlijk enige gegevens over de aansluiting ten behoeve van de wettelijk verplichte 'Schulentwicklungsplanen' (mededeling in interview).

\subsection{Kwalitatieve signalementen}

Meer dan aanvankelijk verwacht (zie hoofdstuk 1) bleek er onder de respondenten vraag naar meer kwalitatieve informatie ten aanzien van de ontwikkeling van de vraag op de arbeidsmarkt: technologische en organisatorische veranderingen in het bedrijfsleven met consequenties voor de omvang, maar vooral ook de aard, van de kwalificatievraag, signalementen van mogelijke ontwikkelingen op dat vlak, signalementen van mogelijke ontwikkelingen in de economische structuur (vestigingen, uitbreiding, nieuwe producten enz.) met eveneens consequenties voor de kwalificatievraag. Onder deze vraag kan eveneens worden verstaan een meer kwalitatieve interpretatie van het cijfermatig materiaal, leidend tot uitspraken waar het managementniveau in de betrokken instellingen, in bedrijven e.d. mee uit de voeten kan. Initiatieven tot een systematische verkenning binnen of dicht bij de bedrijven, leidend tot signalementen op (o.m.) kwalitatief niveau, zijn voornamelijk in (Belgisch) Limburg aangetroffen: de arbeidsmarktprospectie, het arbeidsmarktobservatorium (zie par. 2.3). Wat betreft ZuidLimburg bevat het voorstel van het RBA voor sectorale arbeidsmarktverkenningen het element 'expert-meetings', die vooral bedoeld zijn om het beeld dat uit de kwantitatieve analyses naar voren komt te corrigeren en aan te vullen. Voor het overige zijn alleen meer algemene uitspraken aangetroffen op basis van interpretatie van cijfermateriaal of op basis van landelijke en zelfs internationale trends (o.m. L-SEV en Europees Stimuleringsprogramma Zuid-Limburg, 1994). Overigens is dit type informatie, zeker waar het gaat om technologische en organisatorische ontwikkelingen in het bedrijfsleven en hun consequenties voor de aan ondernemers en werknemers gestelde eisen, weinig regionaal gebonden. In combinatie met kwantitatieve informatie over de 
economische structuur in de Euregio-delen kunnen meer algemene signalementen reeds een zekere waarde hebben. Deze zouden gecombineerd kunnen worden met de uitkomsten van specifieke signalementen in een 'netwerk' binnen de Euregio.

\subsection{Informatie over onderwijs en opleidingen}

Zoals eerder vermeld was de vraag naar informatie over het onderwijs in de andere Euregio-delen opvallend groot. Het lijkt daarbij te gaan om enerzijds feitelijke informatie over het onderwijsaanbod (welke opleidingen waar), b.v. met het oog op mogelijke samenwerking, planning van cursussen e.d., anderzijds om meer inhoudelijke informatie met het oog op 'transparantie'. Vanuit de invalshoek onderwijs-arbeidsmarkt zijn hier vooral de onderwijsvormen met een directe aansluiting op de arbeidsmarkt relevant: het beroepsonderwijs in schools verband en in het verband van het leerlingwezen, opleidingen in het kader van de arbeidsvoorziening en de diverse particuliere opleidingen in de sfeer van de volwasseneneducatie. Het aanbod op het terrein van de volwasseneneducatie is voor de regio Aachen en het aangrenzend Nederlands en Belgisch gebied reeds tweetalig in beeld gebracht door IHK Aachen; er is een initiatief van de stichting Euregio dit overzicht tot een Euregionaal systeem uit te breiden. Dit initiatief betreft -nog- niet het hele onderwijs. Binnen de afzonderlijke Euregio-delen zijn verder diverse overzichten aangetroffen, die echter alleen het eigen gebied betreffen. Wat betreft de meer inhoudelijke beschrijvingen: hier is veel materiaal, maar het probleem is waarschijnlijk het overzicht, toegespitst op de situatie in de eigen (eu)regio. Informatie over het nationale onderwijsaanbod in andere talen wordt b.v. beschikbaar gesteld door vnl. de betreffende nationale ministeries, zij het voornamelijk op vrij globaal niveau. Internationale beschrijvingen en vergelijkingen zijn gepubliceerd door b.v. CEDEFOP. Er lijkt echter geen toegankelijke informatiebron te zijn die gemakkelijk kan worden aangesproken door b.v. werkzaamheden in de arbeidsbemiddeling en de studie- en beroepskeuzevoorlichting; dat geldt temeer voor meer inhoudelijke informatie betreffende het onderwijsaanbod in de eigen (eu)regio. Ook de informatie die inmiddels verzameld is of wordt door de instellingen die zijn belast met de waardering en erkenning van buitenlandse diploma's (in Nederland NUFFIC, COLO en IBG) lijkt nog niet voor andere instellingen toegankelijk.

\subsection{Informatie op Euregio-niveau}

Er is één publicatie aangetroffen waarin jaarlijks een aantal data betreffende de Euregio als geheel worden gepubliceerd: het hoofdstuk 'aangrenzende gebieden' in de Limburgse Sociaal Economische Verkenning L-SEV, jaarlijks uitgebracht door het ETIL (zie par. 3.2). Dit hoofdstuk presenteert van alle Euregio-delen een aantal globale gegevens betreffende de bevolking, de beroepsbevolking, de arbeidsplaatsen, de werkloosheid, de werkgelegenheidsstructuur, het bruto regionaal product en de 
ontwikkelingen in de industrie. Arbeidsmarktgegevens (vraag-aanbodverhoudingen) en onderwijsgegevens zijn niet opgenomen.

\subsection{Resumerend: de mogelijkheden}

In grote lijnen kunnen aangaande de vier in het voorgaande geanalyseerde elementen van een informatiesysteem de volgende conclusies worden getrokken.

1. Arbeidsmarktgegevens: de actuele situatie op de arbeidsmarkt (vraag-aanbodverhoudingen), een aantal voor de arbeidsmarkt relevante economische achtergrondgegevens (economische structuur, vestigingen e.d.) en de actuele bewegingen over de Euregio-grenzen (pendel, evt. vestigingen) kunnen in alle drie Euregiodelen betrekkelijk volledig, voor een deel vergelijkbaar en tegen relatief lage kosten in beeld worden gebracht. De grootste beperkingen betreffen hier de aanbodzijde, als gevolg van het ontbreken van onderwijsstatistiek op matrix- of cohortbasis en van aansluitingsonderzoek in Duitsland en België. Een Euregionaal overzicht van deze gegevens kan op korte termijn worden samengesteld. Deels kan dit bestaande publicaties omvatten, deels secundaire bewerking van aanwezige gegevensbestanden. Een verdere uitwerking van dit overzicht met het oog op een zo groot mogelijke volledigheid en vergelijkbaarheid van de gegevens vergt daarnaast afzonderlijk ontwikkelingswerk.

Waar het gaat om de arbeidsmarktprognoses kan op bestaand werk worden aangesloten in Nederland en Vlaanderen. In Duitsland is er het voornemen tot het opbouwen van een systeem met ondermeer regionale prognoses. Er bestaan echter grote verschillen in de gehanteerde prognosemodellen en in de gegevensbasis. Op termijn zal het in principe mogelijk moeten zijn voor alle drie Euregiodelen prognoses naast elkaar te presenteren; het ontwikkelen van vergelijkbare prognoses moet echter worden gezien als een afzonderlijk project waaraan voorlopig veel haken en ogen zitten.

2. Aansluiting onderwijs-arbeidsmarkt: hier kan alleen op bestaand materiaal worden voortgebouwd v.w.b. het Nederlands Euregiodeel. Voor de andere Euregio-delen kunnen wel een aantal uitstroom-gegevens uit de onderwijsstatistiek worden gelicht. Voor wat betreft Regio Aachen kunnen bovendien de gegevens over de leerplaatsen als indicatie worden gebruikt. In België zijn concrete plannen in de richting van een regelmatig onderzoek naar de aansluiting onderwijs-arbeidsmarkt, die bovendien in overleg met het ROA worden ontwikkeld, zodat goede afstemming mogelijk is. In Duitsland is geen initiatief terzake aangetroffen. Gezien het grote belang van dit type gegevens, zowel binnen het eigen land c.q. de eigen regio als met het oog op internationale informatiesystemen loont het de moeite te zoeken naar mogelijkheden in de Duitse en Belgische Euregiodelen vergelijkbaar onderzoek op poten te zetten, liefst (maar niet noodzakelijkerwijs) als onderdeel van of aanzet tot landelijke onderzoeken. 
3. Kwalitatieve signalementen: een relevant initiatief terzake is voornamelijk aangetroffen in (Belgisch) Limburg; verder kunnen de recente voorstellen van RBA Zuid-Limburg (expert meetings) worden genoemd. De gegevens die uit het Limburgse arbeidsmarktobservatorium voort zullen komen kunnen, zeker waar het om technologische en organisatorische ontwikkelingen binnen sectoren/bedrijfstakken gaat, ook voor de andere Euregiodelen relevant zijn. Publicatie op enige wijze binnen het Euregionaal Informatiesysteem Onderwijs-Arbeidsmarkt lijkt dus gewenst. Daarnaast kan worden onderzocht of een vergelijkbare opzet binnen de andere Euregio-delen mogelijk is. Naast de Limburgse opzet (waarbij observatoren tegen vergoeding worden ingeschakeld) kan daarbij aan een meer informeel netwerk van betrokkenen binnen het bedrijfsleven worden gedacht, aansluitend bij bestaande netwerken en/of in de vorm van regelmatige 'expert-meetings' (RBA-voorstel).

4. Informatie over onderwijs: een goede beschrijving van het hele onderwijsaanbod in de Euregio is wenselijk. Aansluitend bij het lopende initiatief ten aanzien van het volwassenenonderwijs en de in de Euregiodelen aanwezige overzichten van het reguliere onderwijs moet dit zeker mogelijk zijn. Waar het gaat om de meer inhoudelijke beschrijving van het onderwijsaanbod ten behoeve van transparantie: dit is een project dat de schaal van de Euregio Maas-Rijn verre overstijgt. Inhoud en eindtermen van het (reguliere) onderwijs zijn voor een aanzienlijk deel landelijk bepaald en behoeven dus niet regionaal beschreven te worden; een vergelijkbare vraag is te verwachten in de andere Euregio's en meer in het algemeen binnen instellingen die met de internationalisering te maken hebben. Een advies zou kunnen zijn dat de opdrachtgever hier, in overleg met de betrokken ministeries in Vlaanderen en Nordrhein-Westfalen, initiatief neemt. 



\section{De ontwikkeling van een informatiesysteem}

\subsection{Conclusies}

In de voorgaande hoofdstukken heeft een verkenning plaatsgevonden van de behoeften aan een Informatiesysteem Onderwijs-Arbeidsmarkt voor de Euregio Maas-Rijn en de mogelijkheden om tot een dergelijk informatiesysteem te komen. In hoofdstuk 2 werd een potentiële behoefte aan informatie vastgesteld bij instellingen op het gebied van de arbeidsvoorziening en de studie- en beroepskeuzevoorlichting, intermediaire organen ten behoeve van arbeidsmarkt en economie, onderwijsinstellingen en autoriteiten, werkgevers(organisaties), overheden, de Euregionale instanties en tot slot de media en het publiek. In hoofdstuk 3 werden de mogelijkheden vastgesteld om in deze behoeften te voorzien. Voor vier mogelijke componenten van een informatiesysteem (arbeidsmarktgegevens, aansluiting onderwijs-arbeidsmarkt, kwalitatieve signalementen en informatie over onderwijs) werden de beschikbare gegevens en de mogelijk op korte termijn te ontwikkelen gegevens geïnventariseerd. Daarbij kwamen veel mogelijkheden naarvoren, maar ook een aantal beperkingen en onmogelijkheden.

De voornaamste conclusie die uit het voorgaande kan worden getrokken is dat een Informatiesysteem Onderwijs-Arbeidsmarkt

a. aansluit bij concrete behoeften van diverse instellingen in de Euregio;

b. aansluit bij een aanzienlijke 'latente vraag', die waarschijnlijk geactiveerd kan worden door het aanbieden van bruikbare informatie;

c. voor een deel gevoed kan worden uit bestaande informatie, maar wel aanvulling en afronding behoeft in de vorm van een samenvattende publicatie en enige nieuwe gegevensbronnen en publicaties;

d. daarom het beste gefaseerd ontwikkeld kan worden;

e. zoveel mogelijk dient te worden gedragen door een netwerk van betrokken instellingen.

In dit slothoofdstuk worden de consequenties getrokken voor de ontwikkeling van het informatiesysteem. Kernvragen zijn daarbij:

1. welke vorm en functie zal het systeem hebben ?

2. hoe dient de gefaseerde ontwikkeling te worden aangepakt?

\subsection{Vorm en functie van het informatiesysteem}

Uit de bovengenoemde conclusies c. en d. vloeit voort dat het informatiesysteem niet moet worden gezien als één publicatie (of één 'expertsystem' of andere publicatievorm), maar als samenhangend stelsel van deels bestaande, deels nieuw te ontwikkelen publicaties waarbinnen een geleidelijke integratie plaatsvindt. 
Het informatiesysteem dient, in alle opeenvolgende fasen van integratie, zoveel mogelijk de volgende functies te vervullen:

A. Monitoring: permanente waarneming door het periodiek publiceren van kerngegevens betreffende

* de arbeidsmarkt: vraag-aanbodverhouding naar bedrijfssector, beroep en opleiding;

* de aansluiting onderwijs-arbeidsmarkt;

* kwalitatieve ontwikkelingen, vooral aan de 'vraagkant' (kwalificaties).

Deze kerngegevens dienen vooral een signaalfunctie te hebben ten aanzien van:

* knelpunten in de vraag-aanbodverhoudingen en in de kwantitatieve en kwalitatieve aansluiting;

* kansen: bij voorbeeld op het vlak van het bemiddelingsbeleid, te ontwikkelen scholingsaanbod of bedrijfsvestigingen.

Door de nadruk op knelpunten en kansen ondersteunt het systeem de beleidsbepaling van de betrokken instellingen: reageren op wat mis gaat of dreigt te gaan, inspelen op de kansen die zich voordoen.

B. trends en prognoses: verwachtingen op korte en middellange termijn ter ondersteuning van beleidsvoorbereiding en -bepaling. Voorshands zouden deze vooral betrekking dienen te hebben op:

* de ontwikkeling van de werkgelegenheidsstructuur;

* de instroom van schoolverlaters op de arbeidsmarkt;

* verwachte kwalitatieve ontwikkelingen, vooral aan de 'vraagkant' (kwalificaties).

C. ondersteunende informatie: informatie waarop kan worden teruggevallen bij de voorbereiding en uitvoering van beleid. Hierbij kan ondermeer worden gedacht aan:

* de 'opleidingengids': actueel overzicht van opleidings- en scholingsaanbod in de Euregio;

* de 'vacaturebank': actueel overzicht van openstaande vacatures in de Euregio-delen en in EURES;

* de 'kwalificatie-gids': inhoudelijke beschrijving van onderwijsprogramma's en opleidingen en de gerealiseerde kwalificaties, vergelijkbaarheid, wettelijke bepalingen dienaangaande en dergelijke.

Wat betreft de vorm van het informatiesysteem: de drie hierboven onderscheiden functies vallen niet samen met drie afzonderlijke publicaties; het zijn functies die door het geheel van bestaande en nieuwe publicaties zullen moeten worden vervuld. Ten aanzien van de vorm van deze publicaties, de eigenlijke informatieproducten, is wel een aantal zaken vast te stellen.

1. Er zijn ten aanzien van de verschillende onderdelen van het informatiesysteem verschillen tussen de betrokken instellingen in de mate van detaillering ofwel het 
aggregatieniveau waarop men een informatiebehoefte heeft. Wenselijk is dus een modulair informatiesysteem, dat op specifieke gebruikers(groepen) toegesneden publicaties mogelijk maakt zonder dat de kosten daardoor teveel stijgen.

2. De informatie wordt overwegend per Euregiodeel geordend (evt. met uitzondering van de kwalitatieve ontwikkelingen). De gegevens worden zoveel mogelijk vergelijkbaar gemaakt, maar waar dat niet, of niet zonder te groot verlies van informatie, mogelijk is worden de gegevens zo goed mogelijk naast elkaar geplaatst. Overweging is hier dat de informatiebehoeften van de betrokken instellingen niet zozeer vergelijkingen tussen alswel een goede blik op de andere Euregio-delen betreffen. De meeste informatiebehoefte betreft immers concrete actiemogelijkheden aan de andere kant van de grens.

3. Voor een daadwerkelijk gebruik, zeker op het uitvoerende niveau van de betrokken instellingen, is het noodzakelijk dat de informatieproducten in het Duits, Frans en Nederlands worden aangeboden. Daarnaast moet het mogelijk zijn op verzoek specifieke producten in het Engels te leveren, b.v. ten behoeve van buitenlandse bedrijven die geïnteresseerd zijn in vestiging.

\subsection{Gefaseerde ontwikkeling}

Het informatiesysteem wordt, zoals boven aangegeven, gezien als een stelsel van deels bestaande, deels te ontwikkelen publicaties waarin geleidelijk een vorm van integratie wordt aangebracht. Om deze gefaseerde ontwikkeling in kaart te brengen wordt een onderscheid gemaakt tussen

a. reeds bestaande informatieproducten, die geheel of gedeeltelijk, al dan niet aangepast, deel van het systeem kunnen uitmaken;

b. nieuwe informatieproducten die op basis van aanwezige gegevens en publicaties relatief eenvoudig kunnen worden ontwikkeld;

c. nieuw te ontwikkelen informatieproducten: de onderdelen van het systeem die de ontwikkeling van nieuwe modellen en/of nieuwe gegevensbronnen vergen.

Met andere woorden: het informatiesysteem wordt gezien als het resultaat van een netwerk van activiteiten en de daarbij betrokken instellingen. Zo bezien zal het informatiesysteem niet alleen voor, maar ook van de betrokken instellingen zijn. Toch mag het informatiesysteem ook weer niet te vrijblijvend worden benaderd. Een aanzienlijk deel van de informatie die in het systeem kan worden opgenomen is ook nu beschikbaar. Toch beschikken niet alle betrokken instellingen over alle relevante informatie, en/of zij maken er weinig gebruik van. De oorzaak hiervan is het gegeven dat relevante informatie van verschillende 'leveranciers' moet worden betrokken, onder diverse condities, met grote verschillen in de vorm van presentatie en bovendien in verschil- 
lende talen; informatie bovendien die zelden volledig tegemoet komt aan alle beleidsmatige en praktische vragen die eraan gesteld worden.

$\mathrm{Er}$ is dus wel degelijk een aanzienlijke inspanning te leveren om de aanwezige en de op korte en wat langere termijn te ontwikkelen onderdelen van het informatiesysteem te bundelen tot een herkenbaar en bruikbaar informatiesysteem. Deze inspanning zal in nauw overleg tussen, en voor een deel door, de betrokken instellingen moeten worden geleverd. Om dit proces op gang te brengen is een aanzet, een initiatief, op Euregionaal niveau zeer aan te bevelen. Ook de beschikbaarstelling van middelen op Euregionaal niveau ten behoeve van het opbouwen van het systeem, dus van het 'netwerk' en daarbinnen van enige informatieproducten, zal als startsubsidie noodzakelijk zijn.

$\mathrm{Bij}$ a, reeds bestaande informatieproducten: hier kunnen worden genoemd: EURES (m.n. het informatiesysteem arbeidsvoorwaarden en sociale zekerheid), RAMONA, REGARIS, de sectorale arbeidsmarktverkenningen, het arbeidsmarkt-observatorium, de 'opleidingengids' (initiatief IHK en Euregio-bureau), de vacature-uitwisseling 'on line' (nog uit te bouwen tussen RBA en VDAB en FOREM), de L-SEV en de periodieke publicaties van Arbeitsamt, FOREM, VDAB en RBA. Verdere verkenning kan mogelijk nog uitbreiding van deze lijst opleveren. Afzonderlijke vermelding, want buiten de kaders van de Euregio, verdienen de beschikbare informatiebronnen betreffende de onderwijsstelsels van Nederland, België en Duitsland, nodig voor de 'kwalificatiegids'. Het advies aan de opdrachtgever, c.q. de betrokken landsregeringen, is initiatief te nemen tot een bruikbaar inhoudelijk informatiesysteem dat aan manifeste behoeften in verband met de internationalisering van het onderwijs, bij voorbeeld in de Euregio's, tegemoet komt.

$\mathrm{Bij} \mathrm{b}$, nieuwe informatieproducten op basis van aanwezige gegevens en/of publicaties: op dit punt worden aanbevolen:

1. de ontwikkeling van een Euregionaal overzicht onderwijs-arbeidsmarkt. Ten opzichte van het geheel van bij a. genoemde informatieproducten wordt in dit overzicht een verdere integratie nagestreefd, voorzover deze mogelijk is op basis van het aanwezige uitgangsmateriaal, dus de ruwe data die in ieder van de Euregio-delen beschikbaar zijn. Eenmaal ontwikkeld kan dit overzicht, uiteraard slechts binnen het kader van het Euregionaal informatiesysteem, een deel van bovengenoemde bestaande activiteiten en publicaties vervangen. Het gaat hier met andere woorden ook om een geleidelijke integratie van aanwezige informatiesystemen.

2. de uitbouw van het arbeidsmarkt-observatorium en vergelijkbare initiatieven tot een kwalitatief signalement op Euregionaal niveau. 
Bij c, (deels) nieuw te ontwikkelen informatieproducten: hier kunnen tot slot worden aanbevolen:

1. aansluiting ondenwijs-arbeidsmarkt, ondermeer op basis van empirisch schoolverlatersonderzoek;

2. prognoses van ontwikkelingen op de Euregionale arbeidsmarkt.

\subsection{Globale planning, organisatie}

Gefaseerde ontwikkeling impliceert spreiding van de ontwikkelingsactiviteiten over een aantal jaren, dus ook spreiding van kosten. Globaliter zou de fasering van de activiteiten de volgende kunnen zijn:

1. afstemming bestaande informatieproducten en ontwikkeling Euregionaal overzicht onderwijs-arbeidsmarkt: deze activiteiten kunnen op korte termijn worden aangepakt. De voorbereidende werkzaamheden, met name de inventarisatie van gegevensbronnen en publicaties, heeft voor een deel reeds plaatsgevonden in het kader van deze pilotstudy. Onder afstemming van bestaande informatieproducten kan worden verstaan: betere beschikbaarstelling binnen de Euregio, betere afstemming en vermijden van overlappingen, gedeeltelijke vertaling van bepaalde publicaties e.d. Deze activiteit zal vooral binnen en door het te vormen netwerk van instellingen kunnen worden uitgevoerd. Het Euregionaal overzicht kan het beste in directe relatie tot de bestaande producten worden ontwikkeld, opdat afstemming van meet af aan is gewaarborgd en geleidelijke integratie mogelijk is. De ontwikkeling van dit overzicht zal, in nauw contact met het netwerk, door een professionele organisatie moeten worden uitgevoerd.

2. onderzoek aans/uiting onderwijs-arbeidsmarkt: het hiervoor noodzakelijke schoolverlatersonderzoek dient in de Belgische en Duitse Euregio-delen nog van de grond te worden getild, wat betreft Limburg op basis van reeds genomen initiatief. Gezien het cruciale belang van dit type onderzoek, ook als gegevensgrondslag betreffende de arbeidsmarkt, wordt voorgesteld het onder de nieuwe activiteiten prioriteit te geven.

3. ontwikkeling kwalitatieve signalementen: op basis van het netwerk van betrokken instellingen kan tegen betrekkelijk lage kosten een 'observatorium' worden opgebouwd en functioneren. Aan de opbouw en coördinatie dienen echter hoge eisen te worden gesteld. Bovendien zijn de activiteiten waarop dit informatieproduct moet worden gebaseerd, het arbeidsmarkt-observatorium en de expert-meetings (RBA-voorstel sectorale arbeidsmarktverkenningen), nog in de ontwikkelings- resp. initiatieffase. Daarom kan dit onderdeel beter iets later worden aangepakt.

4. prognosemodel Euregionale arbeidsmarkt: voor het genereren van goede prognoses zal een verdere ontwikkeling van de beschikbare gegevens noodzakelijk zijn. Met name is het zeer gewenst dat de uitkomsten van het aansluitingsonderzoek (zie 
bij 2) beschikbaar zijn. Dit onderdeel zal daarom als laatste worden aangepakt. Overigens kunnen reeds beschikbare of binnenkort te ontwikkelen prognoses van meet af aan worden meegenomen en kunnen uitspraken over trends ook worden gebaseerd op het overzicht van de Euregionale arbeidsmarkt en de kwalitatieve signalementen.

Tot slot de organisatie van het Euregionaal Informatiesysteem Onderwijs-Arbeidsmarkt. Binnen het uitgangspunt van een informatiesysteem van en door de betrokken instellingen past het niet één centrale organisatie te belasten met de informatieverzameling en -publicatie. Ook uit kostenoogpunt is dit niet aan te bevelen. Er zal dus primair moeten worden gevaren op de koers van samenwerking en afstemming: 'Euregiostat' in netwerkvorm.

Voor het functioneren van dit netwerk is het wel noodzakelijk dat duidelijkheid wordt geschapen over de verantwoordelijkheid voor de initiatief- en coördinatiefuncties. Het netwerk zal dus enige structuur moeten hebben. Het ligt voor de hand deze structuur te relateren aan de Stichting Euregio Maas-Rijn, maar de initiatief- en coördinatiefuncties behoeven niet noodzakelijkerwijs bij de Stichting te berusten. Het is eerder aan te bevelen deze bij professionele organisaties onder te brengen. Ook een deel van het ontwikkelingswerk en het onderhouden van een deel van de informatieproducten zal aan professionele (onderzoeks)organisaties moeten worden overgelaten. Dit geldt vooral voor het Euregionaal overzicht onderwijs-arbeidsmarkt, het aansluitingsonderzoek en het prognosemodel. 


\section{Literatuur}

Algemene Planningsdienst, Ministerie van de Vlaamse Gemeenschap, Conjunctuurnota voor Vlaanderen, oktober 1994, Brussel, 1994.

Algemene Planningsdienst, Ministerie van de Vlaamse gemeenschap, Vlaamse regionale indicatoren, september 1994, Brussel, 1994.

Arbeidsvoorziening Zuid Limburg, Kwartaalbericht tweede kwartaal 1994, Maastricht, 1994.

Arbeitsamt Aachen, Presseinformation nr. 56/94, Berichtmonat Oktober 1994, November, 1994. Arbeitsamt Aachen, die Berufsberatung, Info zu Beruf und Studium in NRW 94/95.

Arbeitsamt Aachen, Sozialversicherungsverplichtig Beschäftigte im Arbeitsamtbezirk Aachen am 31.03.94.

Arbeitsamt Aachen, Presseinformation nr. 49/93: zweite Analyse der Pendlerstrukturen des Arbeitsamtbezirkes Aachen, September, 1993.

Arbeitsamt, PMS, Über die grenzen hinweg / par dela les frontières; eine Ausbildung zwischen Köln und Lüttich / la formation entre Cologne et Liège.

Bakos, A., Projectvoorstelling arbeidsmarktprospectie; notitie t.b.v. studiebijeenkomst WAV 21 november 1994, Strategisch Plan Limburg, Hasselt, 1994.

Bastelaer, A. van, J. Laan, The Job Vacancy Survey in The Netherlands, in: J. Muysken (ed.), 1994.

Bosker, K., Een 'nieuwe' structuur voor Internationale Diplomawaardering (IDW) in Nederland, LDC, Leeuwarden, 1994.

Brusten, G., P. de Coninck, B. van Schel, Measurement and Analysis of Vacancies in Flanders, in: J. Muysken (ed.), 1994.

Buist, D., J. van Gils, M. Vermeulen, RANBO, een model voor de prognose van het regionaal arbeidsaanbod, INRO-TNO i.o.v. CBA, Rijswijk, 1993.

Bundesanstalt für Arbeit, Ausbildung-Beschäftigung-Zukunftaspekte: anerkannte Ausbildungsberufe in regionaler Gliederung; Ausgabe 1993, Nürnberg, 1993.

Bundesanstalt für Arbeit, Presseinformation nr. 1/94: Arbeitsmarktzahlen für Dezember 1993, Bundesgebiet West, Nürnberg, Januari, 1994.

Bundesanstalt für Arbeit, Beruf aktuell, Überreicht von der Berufsberatung des Arbeitsamtes, Ausgabe 1994/95, Nürnberg, 1994.

Bundesanstalt für Arbeit, Bildung und Beruf regional, Bildungsraum Aachen/Düren; berufliche Grundbildung, Ausbildung und Umschulung, Studiengänge an Hochschulen, berufliche Weiterbildung, BW Bildung und Wissen Verlag, Nürnberg, 1993.

Bundesministerium für Bildung und Wissenschaft, Europa-mittler für Bildung und Wissenschaft in Deutschland, Bonn, 1994.

Buren, grensoverschrijdend tijdschrift, Aan hetwoord: Henk Lentink, vol. 3(1194), nr. 2, juni 1994. CBS/SDU, Standaardberoepenclassificatie 1992, 's Gravenhage, 1993.

Centrale voor Studie- en Beroepskeuze Oriëntering, CSBO, Starten in het secundair onderwijs, 5e uitgave 1994.

COA, EUREQUA, aanzet voor een sterkere grensoverschrijdende samenwerking op het gebied van de beroepskwalificatie in de Euregio Maas-Rijn, Maastricht, 1992.

Commissie van de Europese Gemeenschappen, EURES, het nieuwe netwerk van informatie over de werkgelegenheid, Brussel, 1992.

Commission of the European Communities, Employment Observatory, Trends, Changes in Employment, Analyses, Evaluations, Series produced from the SYSDEM-network, 1994. 
Dam, J.W. van, A. de Grip, J.A.M. Heijke, Naar een Euregionale arbeidsmarkt Maas-Rijn, Economisch Statistische Berichten 77 (1992)3853, blz. 321-324 (ROA-overdruk nr. 35).

Dam, J.W. van, A. de Grip, H. Heijke, Towards a Maas-Rhine Euro-Regional Labour Market, European Business and Economic Development, 1(1993)6.

Dam, J.W. van, A. de Grip, De Euregionale arbeidsmarkt: van fictie naar werkelijkheid, ROA-R1991/10, Maastricht, 1991.

De Euregio Maas-Rijn, informatiedocument Euregionale ontmoeting van 10 december 1993.

Dejonckheere, H., Regionale arbeidsmarktinformatie in Vlaanderen, Tijdschrift voor Arbeidsvraagstukken, 10(1994)1.

Dejonckheere, H., K. Timmerman, De RSZ-statistieken en de LATG-databank; een tweede studiemiddag, een tweede gebruikersgroep? Nieuwsbrief WAV.

Dekker, R.J.P., A. de Grip, L. Borghans, A.G.M. Matheeuwsen, M.H. Wieling, E.J.T.A. Willems, Methodiek van het Informatiesysteem Onderwijs-Arbeidsmarkt 1993, ROA-W-1993/3, Maastricht, 1993.

Denys, J., Winnaars en verliezers op de arbeidsmarkt, Hoger Instituut voor de Arbeid HIVA, KU Leuven, 1991.

Deutsche Bundesbank, Monatbericht November 1993, Frankfurt am Main, 1993.

ETIL, L-SEV '93, Limburgse Sociaal-Economische Verkenningen 1993, Maastricht, 1993.

ETIL, L-SEV '94, Limburgse Sociaal-Economische Verkenningen 1994, Maastricht, 1994.

EURES, Brochure van de Commissie van de Europese gemeenschappen.

Europees Stimuleringsprogramma Zuid-Limburg, Perspectief voor Zuid-Limburg, ontwikkelingsprogramma 1994-1996 EFRO/ESF doelstelling 2-programma Zuid-Limburg, Heerlen, 1994.

EUROSTAT, Labour Force Survey, Methods and Definitions, 1992 series, Luxembourg, 1992.

Franz, W., W. Smolny, The Measurement and Interpretation of Vacancy Data and the Dynamics of the Beveridge Curve: the German Case, in: J. Muysken (ed.), 1994.

Frederix, L.L.M., Th. Mensen, Klantgerichte informatie over onderwijs en arbeidsmarkt in de Euregio, Beroepsopleiding (CEDEFOP), nr. 1, 1993.

Gemeente Maastricht, Gemeentelijk arbeidsmarktbeleid, nota, 1993.

Gewestelijke Ontwikkelings Maatschappij Limburg, Economisch Rapport december 1994, Hasselt, 1995.

Gewestelijke Ontwikkelings Maatschappij Limburg, Actieterreinen vande GOM-Limburg, Hasselt. Gewestelijke Ontwikkelings Maatschappij Limburg, Economisch Rapport november 1993, Hasselt, 1995.

Gewestelijke Ontwikkelings Maatschappij Limburg, Jaarverslag 1993 G.O.M.-L.E.R., Hasselt, 1994.

Gewestelijke Ontwikkelings Maatschappij Limburg, Integraal ontwikkelingsplan Limburg 2010, syntheserapport, Hasselt, 1994.

Gewestelijke Ontwikkelings Maatschappij Limburg, Economisch Rapport mei 1994, Hasselt, 1995.

Gos, E, J. Pacolet, Plus est en vous, Kwalificatieverschuivingen en toekomstperspectieven op de Belgische arbeidsmarkt, Hoger Instituut voor de Arbeid HIVA, Leuven, 1991.

Grip, A. de, Meer licht op de regionale arbeidsmarkt, ROA-R-1991/4, Maastricht, 1991.

Grip, A. de, H. Heijke, Manpower Planning and Labour Market Indicators, ROA, 1994.

Grip, A. de, Regionaal arbeidsmarkt informatiesysteem Limburg, eenverkennende analyse, ROAR-1993/6, Maastricht, 1993.

Hilst, L. van, Integraal ontwikkelingsplan Limburg 2010, deelrapport arbeidsmarkt; Gewestelijke Ontwikkelings Maatschappij Limburg, Hasselt, 1993. 
Hoevenberg, J., P.J.E. van de Loo, R.K.W. van der Velden, Instruments for Analysing Skills Shortages, ROA-W-1994/5E, Maastricht, 1994.

Hoevenberg, J., A. de Grip, Indicators of Occupational Employment in the European Union, ROAR-1994/3E, Maastricht, 1994.

Industrie- und Handelskammer zu Aachen, Lehrstellen-Atlas 94/95, Verzeignis der Unternehmen im Bezirk, die Ausbildungsstellen, Praktikantenstellen und Betriebsbesichtigungen anbieten, Aachen, 1994.

Industrie- und Handelskammer zu Aachen, Weiterbildungshandbuch / bijscholingsoverzicht, overzicht van opleidings- en bijscholingsinstituten in de economische regio Aken en de aangrenzende gebieden van Nederland en België, Aachen, 1994.

Laan, L. van der, Regionale arbeidsmarktinformatie, EGI, Rotterdam, 1992.

Metze, M., Kansen op werk, de arbeidsmarktperspectieven van opleidingen en beroepen, LDC, Leeuwarden, 1993.

Meyboom, P., Minimumloon, uitkeringsniveau en arbeidsschaarste in de Euregio Maas-Rijn, ROA-W-1992/6, Maastricht, 1992.

MHAL (Maastricht-Aachen-Liège-Hasselt/Genk), Ontwerp ruimtelijk ontwikkelingsperspectief, internationale coördinatiecommissie, 1993.

Pacolet, J., C. van derVoorde, Toekomstperspectieven op de Belgische arbeidsmarkt, Werkgelegenheid, Arbeid, Vorming, nieuwsbrief van het steunpunt WAV.

Muysken, J. (ed.), Measurement and Analysis of Job Vacancies, an International Comparison, Avebury GB, 1994.

Nationale Bank van België, Tijdschrift van de nationale bank van België, LXIX(1994), nr. 11.

Natzijl, H., P. Westra, RAMONA, een regionaal arbeidsmarktmodel voorarbeidsvoorziening, CBA, Rijswijk, 1993.

PETRA, National centre in the Netherlands/LDC, Labour Market Information in Guidance, Report of an Expert Meeting 24-25 February 1994, Leeuwarden, 1994.

Provincie Limburg, INTERREG-II programma 1994-1999, mededeling oktober 1994.

Provincie Limburg, Provinciaal arbeidsmarktprogramma 1989-1992, evaluatienota, Maastricht, juni 1993.

Provincie Limburg, Beleidsnota aansluiting onderwijs en arbeidsmarkt in Limburg, Maastricht, mei 1994.

Publicatieblad van de Europese Gemeenschappen, Mededeling aan de lidstaten tot vaststelling van de richtsnoeren voor operationele programma's van de lid-staten in het kader van een initiatief van de gemeenschap betreffende de ontwikkeling van grensgebieden, grensoverschrijdende samenwerking en geselecteerde energienetten (INTERREG-II), nr. C 180/60, 1 juli 1994.

Researchcentrum voor Onderwijs en Arbeidsmarkt, De arbeidsmarkt naar opleiding en beroep tot 1998, ROA-R-1993/10, Maastricht, 1993.

Sellin, B., The Need for Effective Information Systems for Education and Training Policies for Europe, CEDEFOP, Berlin, 1991.

Statistisches Bundesamt, Statistisches Jahrbuch 1994 für die Bundesrepublik Deutschland, Wiesbaden, 1994

Strategische Plan Limburg, Strategisch Plan Limburg-info, Hasselt.

Switten, M., De arbeidsmarktsituatie van migranten na het secundair onderwijs in het Limburgse mijngebied, schooljaar 1990-1991, Limburgs Instituut voor Onderwijsonderzoek en -oriëntatie, Hasselt, 1994.

Timmerman, K., Het planbureau, nieuwsbrief WAV, blz. 149-153. 
Velden, R.K.W. van der, M.R. Wiendels, De regionale arbeidsmarkt voor schoolverlaters, prototype, LDC-ROA, 1994.

Vlaamse Dienst voor de Arbeidsbemiddeling en Beroepsopleiding (VDAB), Maandbericht Tongeren, november 1994, Tongeren, 1994.

Vlaamse Dienst voor de Arbeidsbemiddeling en Beroepsopleiding (VDAB), Maandverslag Hasselt, november 1994, Hasselt, 1994.

Vlaamse Dienst voor de Arbeidsbemiddeling en Beroepsopleiding (VDAB), Maandbericht Limburg, november 1994, Tongeren/Hasselt, 1994.

Vlaamse Dienst voor Arbeidsbemiddeling en Beroepsopleiding (VDAB), Een overzicht van het volledige opleidingsaanbod en de adressen van de opleidingscentra.

Vlaamse Dienst voor de Arbeidsbemiddeling en Beroepsopleiding (VDAB), Toelichting bij de samenstelling van de tabellen maandverslag, 1994.

Wegerif, M., The Use of Vacancy Data by the Dutch Employment Service, in: J. Muysken (ed.), 1994.

Windham, D.M., Effectiveness Indicators in the Economic Analysis of Educational Activities, International Journal of Educational Research, blz. 575-666, 1988.

Winkel, H., Informationen und Materialien zur Geografie der Euregio Maas-Rhein, Heft 17, die Arbeitsmarktsituation in den Grenzregionen Aachen, Limburg (NL) und Verviers, Arbeitsamt Aachen, 1985.

Zandvliet, C. Th., A.C.H. Hammink, H.W. Knol, S. Romkema, Internationale arbeidsbemiddeling, arbeidsvoorziening OAV-rapport 91-10. 